\title{
Working
}

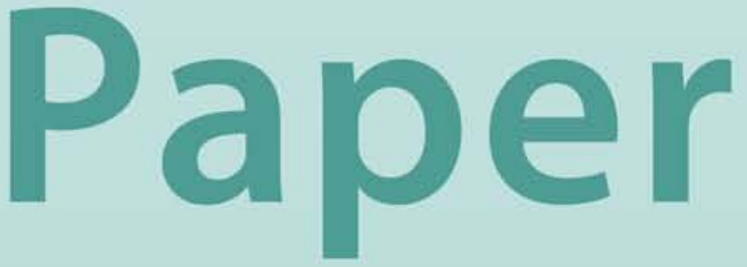




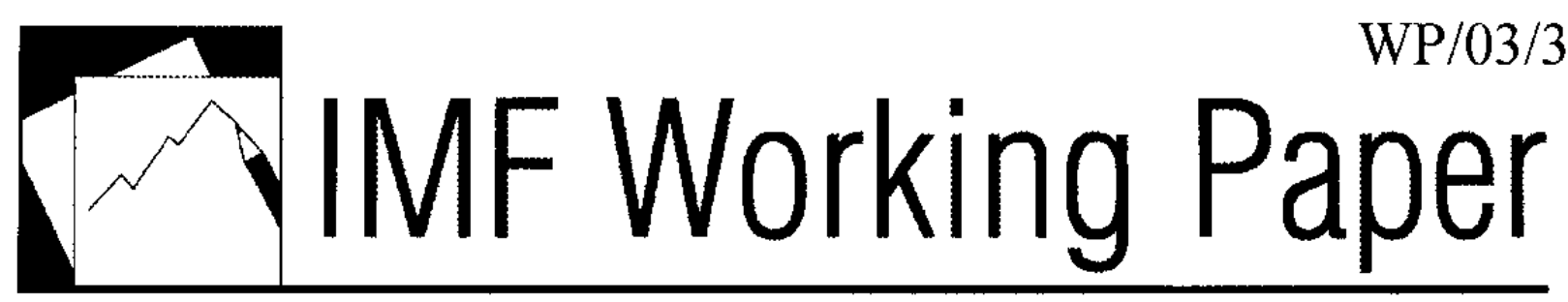

How Much Leverage Is Too Much, or Does Corporate Risk Determine the Severity of a Recession?

Iryna Ivaschenko 


\title{
IMF Working Paper
}

Western Hemisphere Department

\section{How Much Leverage Is Too Much, or Does Corporate Risk Determine the Severity of a Recession?}

\author{
Prepared by Iryna Ivaschenko ${ }^{1}$ \\ Authorized for distribution by Christopher Towe
}

January 2003

\begin{abstract}
The views expressed in this Working Paper are those of the author(s) and do not necessarily represent those of the $\mathrm{MMF}$ or IMF policy. Working Papers describe research in progress by the author(s) and are published to elicit comments and to further debate.
\end{abstract}

Economic theory suggests that financial health of the corporate sector can trigger or worsen an economy-wide recession. This paper proposes a measure of corporate vulnerability, the Corporate Vulnerability Index (CVI), and analyzes whether it can explain the probability and severity of recessions. The CVI is constructed as the default probability for the aggregate corporate sector, using the model of corporate debt by Anderson, Sundaresan, and Tychon (1996). The CVI is shown to be a significant predictor of the probability of a recession 4 to 6 quarters ahead, even controlling for other leading indicators. An increase in the CVI is also associated with an increase in the probability of a more severe and lengthy recession 3 to 6 quarters ahead.

JEL Classification Numbers: E32, E37, E43, E44, G13

Keywords: leverage, structural models of corporate debt, default probability, probability of recession, severity of recession, ranking, probit, ordered probit, forecasting.

\section{Author's E-Mail Address: iivaschenko@imf.org}

\footnotetext{
${ }^{1}$ I wish to thank Paul Soderlind, Paula De Masi, Sam Ouliaris, and Christopher Towe for useful detailed comments. This paper also benefited significantly from comments by Joel Reneby, Calvin Schnure, Philip Young, and seminar participants at the IMF Institute and Stockholm School of Economics.
} 
Contents

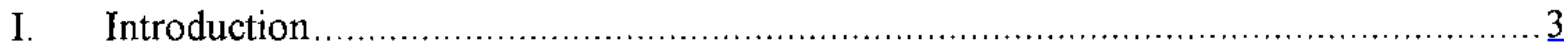

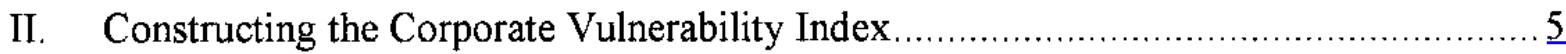

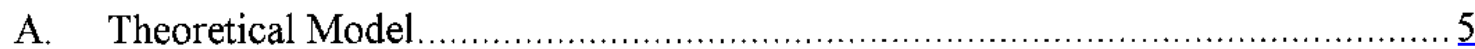

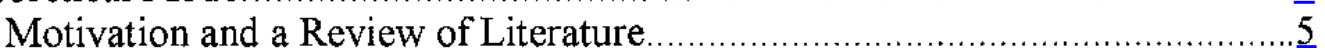

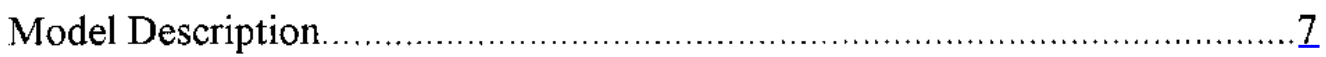

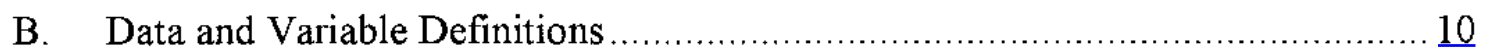

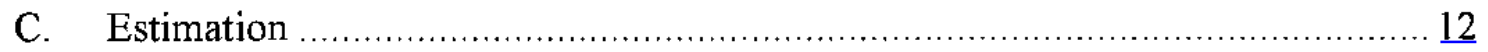

III. Predicting the Probability of Recession......................................................... 14

IV. Predicting the Severity of Recession ........................................................ 15

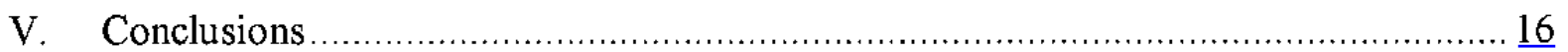

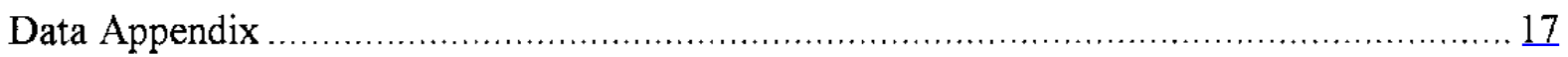

Tables

1. Sample Summary Statistics: Selected Variables ......................................... 20

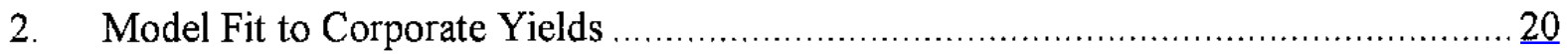

3. Estimation Results of Fitting the Model to Corporate Yield Data............................ 20

4. Predicting the Probability of Recession, Probit Estimations ................................ 21

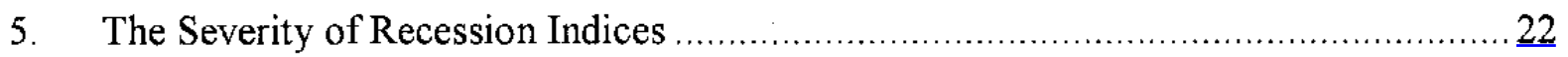

6. Predicting the Severity of Recessions, Ordered Probit Estimations ........................ 23

Figures

1. P/E Ratios of S\&P 500 Composite Stock Index .......................................... 24

2. Corporate Sector: Total Leverage and Corporate Bond Spreads ......................... 24

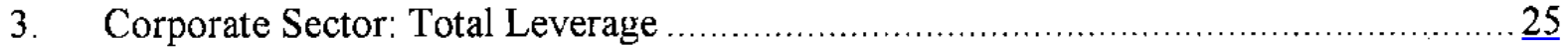

4. Nonfarm Nonfinancial Corporate Sector: Funds Raised .................................25

5. Nominal Corporate Bond Yields: Actual and Fitted ................................... 26

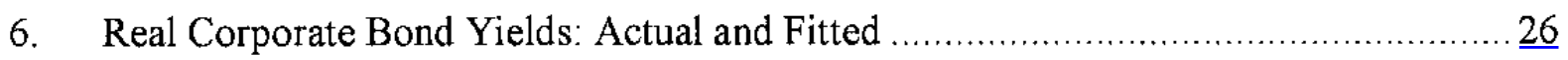

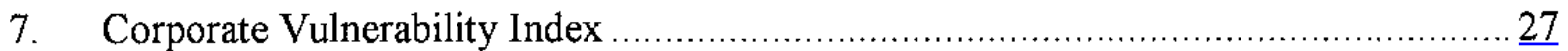

8. Probability of Recession, Predicted with the Corporate Vulnerability Index............. 27

9. Probability of Recession, Predicted without the Corporate Vulnerability Index..........28

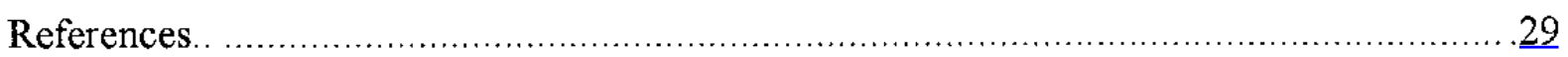




\section{INTRODUCTION}

"... moderate leverage undoubtedly boosts the capital stock and the level of output... the greater the degree of leverage in any economy, the greater its vulnerability to unexpected shortfalls in demand and mistakes."

Greenspan (2002)

The rapid accumulation of corporate debt in the United States during the 1990s raised concerns that the corporate sector had become more vulnerable to sudden economic shocks, such as demand fluctuations and interest rate hikes, and that the high level of corporate debt might prolong the downturn and hinder the ensuing recovery. This paper presents empirical evidence that corporate indebtedness alone does not explain the likelihood or severity of economic downturns. Rather, it is a combination of corporate leverage, future growth prospects, and current macroeconomic conditions that determines whether the economy is susceptible to a slowdown, and whether the slowdown will be severe. The Corporate Vulnerability Index, constructed in this paper as a combination of all these factors, correctly predicts U.S. economic slowdowns, including the 2001 recession, and indicates their severity.

The concerns about the rise in corporate debt are not new. Economists have long recognized that financial conditions of the private sector exert a powerful effect on the macroeconomy. For example, the structural theory of corporate debt directly links increases in leverage with higher corporate risk and thus higher costs of external financing. ${ }^{2}$ Higher funding costs, in turn, tend to reduce investment, depress future cash flows and output, and thus may trigger a slowdown. ${ }^{3}$ Empirical studies corroborate this conjecture by finding that leverage, among other balance sheet indicators, has a major influence on investment spending, inventories, and employment. ${ }^{4}$ Moreover, financial accelerator theory as in Bernanke and Gertler (1990) and Bernanke, Gertler, and Girchrist (1996) suggests that high corporate leverage can make slowdowns more severe by amplifying and propagating initial adverse shocks and by increasing the effects of monetary policy on the real economy (Bernanke and Gertler, 1995). Finally, high debt payments may inhibit an economic recovery by creating liquidity problems

\footnotetext{
${ }^{2}$ See, for example, Merton, 1974). There are a number of other theories modeling the costs of external financing as a function of the firm's balance sheet. See, for example, Kiyotaki and Moore (1997).

${ }^{3}$ In addition, high leverage may lead to credit rationing that limits sources of funding for corporations, thus depressing investment and output. However, with the development of alternative sources of funding for corporations, full-blown credit rationing has become less of an issue, at least for the corporate sector as a whole.

${ }^{4}$ See, for example, Hoshi, Kashyap, and Scharfstein (1991); Gilchrist and Himmelberg (1995); Hubbard, Kashyar, and Whited (1995); Kashyap, Lamont, and Stein (1994); and Sharpe (1994). Bernanke and Gertler $(1986,1990)$ also argued that the strength of balance sheets determined the quality of investment projects undertaken.
} 
that, combined with weak profits, may crowd out productive investments, push up default rates, and erode production capacity.

Financial data illustrate the connection between higher leverage and higher corporate risk. Firms with higher leverage are typically perceived as more risky and pay higher premiums for the market funds they borrow. Indeed, corporate spreads have been increasing in tandem with debt levels and debt burdens since the mid-1990s, despite a continuing strength in equity prices and optimistic expectations about future earnings growth (Figures 1 and 2). An increase in corporate leverage was also accompanied by rising corporate defaults in both investment grade and high-yield sectors, as well as declining recovery rates. ${ }^{5}$ The data indicate that total corporate leverage-defined as a sum of the balance sheet leverage and the debt burden - tends to be higher during recessions (Figure 3).

But how much leverage is too much? According to the structural theory of corporate debt, the cost of external funds is not very sensitive to an increase in leverage if the value of corporate assets is well above the default barrier (a firm defaults if its value falls below this threshold) which in turn depends on the condition of balance sheets, market structure, and macroeconomic variables. Moreover, an increase in leverage may not raise the probability of a corporation going bankrupt if it is offset by improved growth expectations, more favorable debt contract terms, and more accommodative monetary policy. This suggests that the vulnerability of the corporate sector to economic shocks, and thus the probability of recessions, should be related to a combination of variables, rather than corporate leverage alone. Indeed, the probit analysis performed in this paper indicates that, when other leading indicators are controlled for, the corporate leverage looses its forecasting power in predicting the probability of U.S. recessions.

Therefore, in this paper we construct a Corporate Vulnerability Index as a combination of the total corporate leverage, future growth prospects, volatility of the firm value, and current macroeconomic conditions-factors that should affect the corporate default probability and hence the vulnerability of corporate sector according to the structural theory of corporate debt. In particular, this paper uses the model by Anderson, Sundaresan, and Tychon (1996) to choose the combination of factors and factor loadings that govern corporate default probability. To infer how the factors might be combined, the model is fitted to the aggregate corporate bond yield data. The Corporate Vulnerability Index (CVI) is then constructed as the probability of default for the entire corporate sector. ${ }^{6}$

\footnotetext{
${ }^{5}$ In 2001 , the recovery rate fell to a twenty-year low of 21 percent, two times as low as an average for the same period. Sce Moody's (2002).

${ }^{6}$ Although most of the models of corporate debt are developed for an individual firm, Anderson and Sundaresan (2000) showed that they can be successfully fitted to the aggregate data, yielding reasonable parameter estimates. Although the model-derived corporate default probabilities were above historical levels for short horizons and below historical levels for long horizons, overall they were comparable in magnitude to historical default rates for the aggregate corporate sector.
} 
Probit estimation results indicate that the CVI correctly predicts recessions four to six quarters ahead. The CVI remains significant in predicting recessions even when other leading indicators, widely used to predict the probability of recessions, are included in the regression. The probit model using the CVI also predicts the probability of recession more successfully than other forecasting models. In particular, it predicted a high probability of a recession four quarters in advance of the 1990-91 recession, which other widely used leading indicators failed to predict. ${ }^{7}$ Moreover, adding the CVI to the probit model with other leading indicators significantly improves the model's accuracy. For example, the model using the CVI correctly predicted the timing of the recent slowdown four quarters in advance, while the model without the CVI failed to do so.

To test the hypothesis that a vulnerable corporate sector may increase the severity of slowdowns, a variable that ranks recessions with respect to their severity-the Severity of Recession Index (SRI) is constructed-since there has been no such variable in the existing literature. The SRI ranks recessions with respect to the cumulative output loss and length. The SRI is then used as a dependent variable in the ordered probit model. The estimation results indicate that an increase in the CVI is shown to be associated with an increase in the probability of having a more severe recession three to six quarters ahead, regardless of how the severity index is constructed. Moreover, an increase in the CVI also increases the probability of having a longer recession.

The rest of the paper is organized as follows. Section II describes in detail the construction of the CVI. First, it reviews structural models of corporate debt and describes the model used to construct the CVI. After describing the data and the estimation technique used to estimate unknown parameters of the model, it presents the CVI construction. Section III presents the estimation results of the probit model predicting U.S. recessions using the CVI as an explanatory variable. Section IV describes the construction of the Severity of Recession Index and presents the results of the ordered probit estimation using the CVI as an explanatory variable to predict the severity of recessions. Section V concludes.

\section{Constructing the Corporate Vulnerability IndeX}

\section{A. Theoretical Model}

\section{Motivation and a Review of Literature}

The set of factors that comprise a measure of corporate vulnerability and the way they are combined is guided by the model of corporate debt by Anderson, Sundaresan, and Tychon (1996) (AST), applied to a perpetual bond. The choice to work with the AST model, applied to a corporate perpetuity, is guided by several considerations. First, as all other structural

\footnotetext{
${ }^{7}$ This fact is well-documented in the literature. See, for example, Estrella and Mishkin (1997), Dotsey (1998), and Stock and Watson (2000).
} 
models of risky debt, it links the valuation of corporate financial claims to economic variables. Second, the AST model explicitly allows for strategic debt service by shareholders. The point at which a firm defaults - the default barrier-is not given exogenously but is derived as a result of the strategic interaction between creditors and shareholders. In addition, as in many other models, it models bond market features in a realistic fashion, as it allows for costly bankruptcy and deviations from absolute claim priority. Third, modeling aggregate corporate debt as a perpetuity with time-varying coupon payments seems to be the most natural, given that individual firms continuously roll over their existing debts or issue new ones. Finally, the model fits aggregate corporate bond data better than other structural models (see Anderson and Sundaresan, 2000).

The AST model belongs to a class of structural models that are rooted in the approach of Merton (1974) who showed that a firm's debt can be valued as a contingent claim on the market value of a firm's assets and priced within the option-pricing framework of Black and Scholes (1973). In these models, equity has characteristics similar to a call option written on the firm's assets, while the debt claim possesses features of a portfolio consisting of a discount bond and a short call option on the firm's assets. In both cases, the strike price of the option equals the face value of a debt claim. Structural modeling, therefore, links the valuation of corporate financial claims to firm-specific fundamentals, such as growth prospects (expressed in terms of current and future value of its assets) and riskiness (such as leverage and asset volatility), and economy-wide fundamentals such as the short interest rate and common factors driving stock prices. ${ }^{8}$ This feature of structural models is supported by empirical studies showing that spreads between corporate and government bond yields are related to indicators of firm profitability and financial health (Fisher, 1959), business cycle indicators (Duffee, 1998), and economy-wide factors governing equity returns (Elton et al., 2001).

Despite its intuitive appeal, the Merton model fits the data poorly, typically underestimating actual corporate spreads (see Jones, Mason and Rosenfeld, 1984; Franks and Torous, 1989; and Eom, Helwege, and Jing-zhi, 2002). Much of the empirical mismatch comes from the model's simplifying assumptions: corporate debt structure is represented by one noncallable bond; default can occur only at maturity and when a firm exhausts its assets; the firm's asset value is independent of the short interest rate; and strict absolute priority of claims is assumed. ${ }^{9}$ A number of extensions to the original model tried to rectify these shortcomings.

\footnotetext{
${ }^{8} \mathrm{~A}$ number of authors took another approach, called a reduced-form approach, which infers prices of corporate bonds from market benchmarks, modeling default as some random process. See, for example, Litterman and Iben (1991); Jarrow and Turnbull (1995); Jarrow, Lando, and Turnbull (1997); and Duffie and Singleton (1996). Since this approach does not shed light on the relationship between economic factors and corporate default, we chose to work with structural models.

9 Jones, Mason, and Rosenfeld (1984), and Franks and Torous (1989) show that assuming that default can occur only when a firm exhausts its assets implied credit spreads smaller than actual credit spreads.
} 
For example, Geske (1977) models a more complex debt structure; Black and Cox (1976) allow default to occur before the firm exhausts its assets and before maturity; Logstaff and Schwartz (1995) and Ericsson and Reneby (1998) allow for deviation from the strict priority of claims and explicitly incorporate interest rate risk. ${ }^{10}$

However, most of these models treat the default boundary as exogenous, which seems to be an implausible assumption for analyzing the aggregate corporate sector riskiness given the dynamics of the composition of corporate financing. During the latter half of 1990s U.S. corporations increased the magnitude of equity buybacks-amounting to net $\$ 3.65$ trillion by $2000-$-which were largely financed through issuing debt (see Figure 4). This has helped boost equity prices while also increasing firms' leverage and thus riskiness. It has been argued that these developments are to a some extent connected to a shift in managerial incentives, resulting in favoring higher returns on equity even at the expense of the firm's riskiness. ${ }^{11}$ These developments also suggest that corporations, aware of the trade-off between higher returns on equity and higher corporate risk, increasingly chose in favor of the former. It is therefore possible that the market value of a firm's assets, leverage and thus the default barrier are not exogenous, but instead products of strategic decisions made by firm shareholders and managers.

In this respect, structural models that determine the default boundary endogenously are especially useful for the analysis of the aggregate corporate sector. In these models, the default barrier is either determined in a game-theoretic framework of the bankruptcy process as in Anderson and Sundaresan (1996) and Anderson, Sundaresan, and Tychon (1996) or derived using variations of the real options theory of investment that treats liquidation decision as an option as in Mella-Barral and Perraudin (1997).

\section{Model Description}

The AST model develops the price of corporate debt in the following way. Consider a firm, whose assets value, $V_{l}$, follows a geometric Brownian motion:

$$
d V=(\mu-\beta) V d t+\sigma V d W,
$$

where $\mu$ is the rate of return on firm's assets, $\beta$ is the cash flow rate, $\sigma$ is volatility of the asset value, and $d W$ is a standard Wiener process. A firm's debt is modeled as a perpetual bond with the face value $F$ and a coupon $c$. To accommodate the fact that the indebtedness and debt burden of the U.S. corporate sector vary over time, we allow for time-varying debt level, $P_{t}$. One of the key assumptions of the model is that the bankruptcy regime allows for

\footnotetext{
${ }^{10} \mathrm{~A}$ number of studies show that the strict priority of claims is rarely observed in bankruptcy proceedings. See, for example, Franks and Torous (1989, 1994); Ebcrhart, Moore, and Roenfeldt (1990); and Weiss (1990).

${ }^{11}$ See Cookson (2001).
} 
default that does not necessarily lead to liquidation, implying that the flow of debt service is state-dependent, $S_{t}=S(V, c) d t$. The recovery rate given default, $\theta$, is not restricted to equal one. In the event of liquidation, bondholders receive the assets of the firm net of nonzero liquidation costs, which are assumed to be a linear function $K_{t}+\left(1-\theta_{t}\right) V_{t}$, where $K_{t}$ is the bankruptcy cost and $\theta_{t}$ is a debt recovery rate. This implies that the value of debt at liquidation is given by:

$$
B_{t}^{L}=\max \left[\theta_{t} V_{t}-K_{t}, 0\right]
$$

In the case of perpetual bonds and under a simplifying assumption that

$$
S\left(V_{t}, \mathcal{c}\right)=\begin{array}{ll}
P_{t} c & \text { if } V_{t} \geq V_{t}^{*} \\
B_{t}^{L} & \text { if } V_{t}<V_{t}^{*}
\end{array}
$$

the price of a perpetual bond can be expressed analytically:

$$
B_{t}=\frac{c P_{t}}{r_{t}}\left(1-P_{t}^{d}\right)+P_{t}^{d} \max \left[\theta_{t} V_{t}^{*}-K_{t}, 0\right],
$$

where $P_{t}^{d}$ is a probability of default and $V_{t}^{*}$ is a default barrier. ${ }^{12}$ The default barrier in the AST model is endogenously derived from the game-theoretic framework of strategic decisions by shareholders on whether to service debt obligations. Since liquidation involves a dead-weight loss for creditors (i.e., costly liquidation), shareholders might chose to underperform their debt obligations even though they have enough cash at their disposal. By underperforming debt obligations, shareholders can increase the value of equity at the expense of the bond value. However, if shareholders push the debt value too low, debtholders may force a firm into liquidation.

Equation (4) is quite typical for asset pricing theory in general and structural models in particular, as it presents a price of a risky corporate bond as an expected value of a contract function. The value of a risky bond equals the value of a riskless (perpetual) bond, $\frac{c P_{t}}{r_{t}}$, times the probability of no default, plus the recovery value of debt at liquidation, $B_{t}^{L}$, times the probability of default. ${ }^{13}$ In the AST model the probability of default is defined as follows:

\footnotetext{
${ }^{12}$ Note that $V_{t}^{*}$ is called a default barrier not a liquidation barrier meaning that default may or may not lead to the liquidation.

${ }^{13}$ This is a risk-neutral probability of default and thus is not directly comparable to the historical default rates. See Delianedis and Geske (1988) for a discussion.
} 


$$
P_{t}^{d}=\left(\frac{V_{t}}{V_{t}^{*}}\right)^{\gamma_{t}}
$$

where $\gamma_{t}=0.5-\frac{\left(r_{t}-\beta\right)}{\sigma_{t}^{2}}-\sqrt{\left(\left(\frac{\left(r_{t}-\beta\right)}{\sigma_{t}^{2}}-0.5\right)^{2}+\frac{2 r_{t}}{\sigma_{t}^{2}}\right)}<0$ if $r_{t}>\beta$

Although the original AST model assumes fixed bankruptcy cost and a unity recovery ratio, we assume that bankruptcy cost as a percent of the value of assets is constant over time, and allow the recovery ratio be less than unity. Thus, for the case of a perpetual bond, the default barrier is defined as:

$$
V_{t}^{*}=\frac{\left(\frac{c P_{t}}{r_{t}}+K_{t}\right)}{\theta_{t}\left(1-\frac{1}{\gamma_{t}}\right)},
$$

It is worth noting that the liquidation barrier is increasing in the dead-weight cost of bankruptcy, $K_{t}$, and declining in the recovery rate, $\theta_{t}$. Economically, this means that the costlier the liquidation, the greater is the ability of shareholders to extract concessions from creditors. Knowing this, bondholders will demand a greater premium on corporate debt even for corporations far from default, implying higher cost of financing for corporations and resulting, according to (5), in higher default probability. The liquidation barrier is also decreasing in the risk-free interest rate, which suggests that if interest rates are high, shareholders are able to extract greater value at the expense of creditors.

From (5) and (6), the default probability can be expressed as follows:

$$
P_{t}^{d}=\left(1 /\left(\frac{c P_{t} / V_{t}}{r_{t} \theta_{t}\left(1-1 / \gamma_{t}\right)}+\frac{K_{t} / V_{t}}{\theta_{t}\left(1-1 / \gamma_{t}\right)}\right)\right)^{\gamma_{t}}
$$

This is the main equation that will be used to construct the measure of corporate vulnerability in the next section. There are several noteworthy characteristics of this equation. First, the probability of default is increasing in balance sheet leverage, $P_{t} / V_{t}$ and a coupon rate, $c$, indicating that both high levels of balance sheet debt and higher debt burden increase the riskiness of the company and thus should be taken into consideration when measuring total corporate leverage. Second, the probability of default is increasing in the risk-free interest rate, $r_{t}$, if $r_{i}>\beta$-the condition that holds for the most of the sample period analyzed in this paper-indicating that the riskiness of the corporate sector is sensitive to macroeconomic 
conditions. Finally, it is increasing in the volatility of the firm's asset value above a certain level of volatility, and is nonmonotonic below this level. Thus, three factors - total leverage, interest rate, and volatility - should explain changes in the corporate vulnerability over time.

\section{B. Data and Variable Definitions}

We use data on aggregate bond index yields. The aggregate bond index consists of seasoned corporate bonds - those with remaining maturities of at least 20 years - with Baa credit rating, as calculated by Moody's Investors Service. The Baa rating is chosen because an average rating of a company listed in S\&P500 Composite index is Baa; and the median credit quality of all Moody's-rated North American companies (these also include Canadian firms) is approximately Baa. Quarterly data from 1969Q1 to 2001Q4 are used. The choice of frequency is guided by the availability of balance sheet data. A risk-free interest rate is approximated with an average yield on treasury bonds with effective maturities of 10 years or longer (see Data Appendix for a detailed description of the interest rate data). ${ }^{14}$

Total corporate leverage is constructed as a sum of the balance sheet leverage and the debt burden. Balance sheet leverage is constructed from the quarterly observations on aggregate balance sheet data of nonfinancial corporate business from the U.S. Flow of Funds Accounts, compiled by the Board of Governors of the Federal Reserve. ${ }^{15}$ From the debt and equity data we construct the proxy for leverage:

$$
L E V E R_{t}=\frac{D E B T_{t}}{D E B T_{t}+E Q U I T Y_{t}} \text {, }
$$

where $D E B T_{t}$ is market debt owed by the nonfinancial corporate business, stated at book value; and $E Q U I T Y_{t}$ is a market value of outstanding equities. ${ }^{16}$ Both are U.S. dollar amounts outstanding at the end of period.

The balance-sheet-based measure of leverage reflects only one aspect of corporate indebtedness. Practitioners and policymakers also use a flow-based measure of leverage, debt

\footnotetext{
${ }^{14}$ A 30 -year treasury bond would have been the closest match to the corporate bond data we use. However, these data are available starting 1977 only (see Data Appendix).

${ }^{15}$ Anderson and Sundaresan (2000) construct monthly series from the quarterly data from the Flow of Funds Accounts and the annual data from the National Income and Product Accounts (NIPA) using a set of assumptions. In contrast, raw data in the form available from the Flow of Funds and NIPA are used in this paper to make sure that the results are not driven by the way the data are constructed.

${ }^{16}$ Strictly speaking, since equities are neither assets nor liabilities, their value is not reflected on corporate balance sheets. Equities represent corporate capital and are stated at market values as a Memo item in the Flow of Funds. Howcver, the net equity issuance is recorded as an increase in liabilities.
} 
burden - debt service payments as a share of corporate profits or cash flows - to assess the financial health of corporations. Moreover, considering both balance-sheet-based and flowbased measures of leverage is consistent with both stock-based and flow-based definitions of financial distress discussed in Wruck (1990) and Kim, Ramaswamy, and Sundaresan (1992). Accordingly, the debt burden measure is calculated in the following way:

$$
B U R D_{t}=\frac{I N T E R E S T_{t}}{P R O F I T_{t}}
$$

where INTEREST is gross debt payments, calculated as a sum of constituents of aggregate corporate liabilities, multiplied by appropriate interest rates (see Data Appendix for a detailed description); and PROFIT $_{t}$ is corporate profits with inventory valuation and capital consumption adjustments of nonfinancial corporate sector ${ }^{17}$ All figures are available quarterly, seasonally adjusted at an annual rate.

In order to combine level-based balance sheet leverage with flow-based debt burden, we convert flows into levels at each time point $t$ by calculating the present value of the future stream of debt payment flows. Debt payments are assumed to be constant from time $t$ until the maturity of the bond, and are discounted with long corporate bond yield (see Data Appendix for details). ${ }^{18}$ Thereafter, the total leverage is computed as a sum of the balance sheet leverage and the debt burden: ${ }^{19}$

$$
L E V_{t}=L E V E R_{t}+P V_{t}\left(B U R D_{t}\right)
$$

Table 1 presents descriptive statistics of sample corporate yields and measures of leverage (see also Figure 3 ).

\footnotetext{
${ }^{17}$ Capital consumption adjustment converts depreciation and inventory valuation adjustment converts inventory withdrawal from historical to replacement costs, which is the measure used in NIPA.

${ }^{18}$ Another approach would be to rescale $B U R D_{t}$ so that its mean/standard deviation ratio is comparable to that of $L E V E R_{t}$ and to combinc these measures lincarly: $I E V{ }_{-} A S_{t}=\alpha L E V E R_{t}+\kappa \ln \left(\ln \left(B U R D_{t}\right)\right)$. Anderson and Sundaresan (2000) used this method. The results presented in this paper are not sensitive to the construction of the measure of total leverage.

${ }^{19}$ To be sure, any traditional measure of debt derived from the balance sheet data understates the true amount of leverage in the economy due to increasing off-balance-sheet liabilities. Nevertheless, the traditional measures of leverage calculated from the officially reported balance shect data have proved to be useful cven when measuring performance of such major derivatives players as Enron and LTCM. As pointed out by Chairman Greenspan, problems of these firms "were readily traceable to an old fashioned excess of debt, however acquired, as well as to opaque accounting of that leverage..."
} 
The instantaneous volatility of the asset value, $v^{2}$, is unknown. It is assumed to be timevarying, proportional to the volatility of equity returns: $v_{t}^{2}=\left(A \sigma_{t}\right)^{2}$, where $A$ is a constant scaling parameter. The volatility of equity returns is estimated as the square of the rolling standard deviation of quarterly returns on the S\&P500 Composite index, $I_{t}$, over a 12-quarter window. ${ }^{20}$ Returns are calculated as $R_{t}=\ln I_{t}-\ln I_{t-1}$. Parameter $A$ is estimated when the AST model is fitted to the data.

\section{Estimation}

To construct a measure of corporate vulnerability, we first fit the theoretical bond yieldcalculated as $y_{t}=c P_{t} / B_{t}$, where $B_{t}$ is a price of corporate bond, defined in (4)-(7)-to the actual yields on the corporate bond index. Since the value of corporate assets, $V_{t_{2}}$ is unknown, we normalize the model with respect to $V_{t}$, and assume that the ratio of the bankruptcy cost to the asset value, $K_{t} / V_{t}$, the recovery rate, $\theta$, and the dividend rate, $\beta$, are constants. They are inferred from the data.

Given these assumptions, the structural model described in the previous section can be implemented in the following form:

$$
y_{t}=\alpha+y\left(\frac{P_{t}}{V_{t}}, A \sigma_{t}, r_{t} ; \frac{K_{t}}{V_{t}}, \theta, \beta\right)+u_{t}
$$

where $y_{t}$ is the actual yield on the Moody's long-term corporate bond index. The function $y($ ) is the corporate spread implied by the theoretical bond value, $B($.$) , calculated using the model$ (4)-(7), and the formula: $y_{t}=c \frac{P_{t}}{V_{t}} / \frac{B_{t}}{V_{t}}$. The variable $c P_{t} V_{t}$ is approximated as total leverage, described in the previous section. The additive constant, $\alpha$, is included to capture corporate liquidity and tax premiums that are embedded in corporate yields, but are not captured by the AST model. Corporate bonds pay a liquidity premium over treasuries because corporate markets are less liquid than government ones. They also pay a tax premium since interest on treasuries is tax deductible while interest on corporate bonds is not. We assume that the sum

\footnotetext{
${ }^{20}$ We also experimented with another measure of quarterly volatility-realized volatility-defined as a sum of squared daily returns, $R_{t}{ }^{2}$, as in Schwert (1989). This measure is shown to be an unbiased estimator of true volatility in continuous time by Andersen et. al, (2002); and we performed Monte Carlo experiments showing that sampling at a daily frequency provides a reasonably good discrete approximation to the true process governing quadratic variation of quarterly stock returns. Moreover, using nonoverlapping samples to estimate the quarterly variance avoids introducing autocorrelation into estimation error, unlike using the rolling sample standard deviation. However, we chose to work with the sample rolling volatility correcting for moving average in errors due to ease of computation. While the model with realized volatility fitted bond yields slightly better, the results of the forecasting exercise predicting the probability and severity of recession were fairly robust to the choice of a volatility proxy.
} 
of these premiums is constant over time.$^{21}$ Finally, the constant term absorbs any systematic biases in the model of $y($.).

We estimate the parameters $a, K_{t} V_{t}, A, \theta, \beta$ by nonlinear least squares. Since the model is highly nonlinear, to ensure that the global maximum is found, optimization is performed in two steps. First, a generic, nonderivative, method is used to find initial values, which are then used to fit the model to the data by the modified Gauss-Newton method. The model is fitted to both nominal and real corporate bond yields.

The model is estimated in real terms as a robustness check, since the denomination of variables is not a significant factor in the model as long as all variables are expressed in the same terms as a common numeraire - in this case, a price or a yield on a risk-free asset. However, in practice, in periods of high inflation firms tend to switch to different accounting methods; fixed assets tend to be understated and long-term debt levels overstated, which may affect estimation results. Since all balance sheet and flows data are estimated as ratios, only interest rates and bond yields are adjusted for inflation. Inflation data are derived using the implicit GDP deflator from the NIPA. Expected inflation rates are estimated by fitting an $\operatorname{ARIMA}(7,1,3)$ model to quarterly inflation data over the period from $1947 \mathrm{Q} 2$ to $2001 \mathrm{Q} 4{ }^{22}$

The model fits both nominal and real yields well (Figures 5 and 6), with squared errors being less than 10 percent for nominal yield, and less than 14 percent for real yields (Table 2). While the parameters of both nominal and real models are similar, the cost of bankruptcy and the recovery rate are somewhat higher when expressed in real terms (Table 3).

Estimated parameters are then substituted into equation (7) to obtain a measure of corporate vulnerability, which we will call a Corporate Vulnerability Index (CVI) through the rest of the paper. Figure 7 shows that the CVI increased before each recession. The CVI is a nonlinear function, increasing in leverage and the risk-free interest rate, and nonmonotonic in asset volatility. The combination of these factors explained the dynamics of the CVI over the sample period. Since its dramatic peak in the early 1980 s, caused by high interest rates and leverage, the CVI has generally trended down during most of the 1990s, driven by either declining leverage or lower interest rates, indicating the increased resilience of the corporate sector to adverse shocks. The CVI increased modestly at the end of the 1990 s, reflecting the rise in debt levels and the increase in asset volatility, which were partially offset by lower

\footnotetext{
${ }^{21}$ This simplifying assumption is mainly driven by a lack of models that explain the behavior of liquidity premium and tax differential.

${ }^{22}$ This model fits the data well. The residuals appear to be white noise according to both Ljung-Box test and Bartlett tests. Ljung-Box (Q) statistic is 26.02 (with p-value of 0.96) and does not reject the null that the first forty autocorrelations are zero. Bartlett (B) statistics which is 0.45 , with p-value of 0.98 also does not reject the null that residuals are white noisc. Mean absolute crrors are about 20 percent of the mean inflation rate.
} 
interest rates. In general, the CVI increased before every recession, and whether it can predict economic downturns is analyzed in the next section.

\section{Predicting the Probability of Recession}

As suggested by the literature reviewed in the introduction, financial conditions of the corporate sector affect the probability of recessions. To evaluate this hypothesis, we employ a probit model that uses the NBER recession index $\left(R_{t}\right)$ as a dependent variable, as in many previous empirical studies. ${ }^{23}$ The NBER index equals one if the economy is in a recession during the given quarter, and zero otherwise. ${ }^{24}$ To assess the marginal predictive power of the CVI, we include other leading indicators, proved to be good predictors of U.S. recessions by previous studies, such as average weekly hours worked ( $A V G H R S$ ), Conference Board's vendor performance index (VENDOR), housing starts (HOUSING), the slope of the treasury yield curve (TRY_STR), and stock returns (SPRET):

$$
\begin{gathered}
\operatorname{Prob}\left(R_{t+k}=I \mid \Omega_{t}\right)=F\left(c_{0}+c_{l} C V T_{t}+c_{2} A V G H R S_{t}+c_{3} V_{E N D O R_{t}}+\right. \\
\left.-c_{4} H O U S I N G_{t}+c_{5} \text { TRY_SIR }+c_{6} S P R E T_{t}\right)
\end{gathered}
$$

where $F($.$) is a cumulative normal distribution function and \Omega_{t}$ is an information set at time $t$.

The estimation results indicate that the CVI is significant in predicting the probability of recession four to six quarters ahead, even controlling for other leading indicators (Table 4). For example, a 10 percent increase in the CVI is associated with a 0.08 percentage point increase in the probability of recession four quarters ahead. ${ }^{25}$ The fact that the CVI is significant in signaling the probability of recession at longer horizons may indicate that as markets recognize an increase in corporate vulnerability, the cost of external funding rises, and corporations are forced to work on improving their balance sheet positions. By the time the economy slips into a recession, corporate balance sheets have typically begun to improve, thereby lowering the CVI.

\footnotetext{
${ }^{23}$ Literature that uses binary models to evaluate the probability of recessions is vast. To name a few, Estrella and Hardovelis (1991), Stock and Watson (1993), Estrella and Mishkin (1997), Dueker (1997), and Dotsey (1998).

${ }^{24}$ NBER's Business Cycle Dating Committee determines whether the economy is in the recession or cxpansion. A recession is defined as a significant decline in activity spread across the economy, lasting more than a few months, visible in industrial production, employment, real income, and wholesale-retail salcs. Expansion is a period between a trough and a peak of economic activity.

${ }^{25}$ The coefficients from the binary model cannot be directly interpreted as a marginal effect on the dependent variable. The marginal effect of the CVI on the conditional probability of a recession is given by: $\partial \operatorname{Pr} o b\left(R_{t}=1 \mid C V I_{t}, \beta_{C V I}\right) / \partial C V I_{t}=\left(-d F\left(-C V I_{t}^{\prime} \beta_{C V I}\right) / d C V I_{t}\right) \beta_{C V I}$, where $\mathrm{F}($.$) is a cumulative distribution function.$
} 
The model incorporating the CVI more successfully predicts the probability of a recession than traditional models. A high probability of recession was predicted four quarters in advance of the 1990-91 recession. In contrast, other widely used leading indicators failed to predict this recession episode, as documented in Estrella and Mishkin (1997), Dotsey (1998), and Stock and Watson (2000). For example, model (9) predicted an 86 percent probability that the economy would slip into recession in 1990, while the Estrella and Hardovelis (1991) model, which uses the treasury yield curve, implied only 20 percent probability and the Estrella and Mishkin (1997) model, which uses the treasury yield curve and stock prices, implied only a 25 percent probability.

Adding the CVI to other leading indicators significantly improves the model's forecasting accuracy. Model (9) correctly predicted the timing of the recent recession four quarters in advance, while the same model without the vulnerability index failed to do so (Figures 8 and 9). The model with the CVI forecasted a recession with 53 percent probability in the first quarter of 2001, while the model without the CVI placed only a 6 percent probability of a recession in the first quarter of 2001. In addition, the model with the CVI did not produce false recession signals in the mid-1990s, when the economy was in the midst of an expansion, unlike the model without the CVI. Although the model with the CVI suggested a significant jump in the likelihood of a recession from virtually zero in the fourth quarter of 1994 to almost 30 percent in the second quarter of 1995 , the probability was still below 50 percent. In contrast, the model without the CVI implied a 63 percent probability of a recession in the second quarter of 1995.

\section{Predicting the SeVerity of Recession}

To assess whether the higher Corporate Vulnerability Index is associated with a more severe slowdown, as suggested by the theory outlined in the introduction, we first need to construct a variable that would rank recessions with respect to their severity. Since, to our knowledge, there is no such variable existing in the literature, we construct it in the following way. First, the magnitude of a cumulative decline of real GDP between the pre-recession quarter and the last quarter of the recession, normalized by the length of the recession, is calculated. Second, recessions are then ranked, with a higher rank representing a more severe recession or a group of more severe recessions (see Table 5 for a detailed description of ranking rules). The resulting variable is called a Severity of Recession Index (SRI). Several different rules were used for grouping the recessions according to their severity - to obtain different variations of the SRI-to check the robustness of the results. Another Severity of Recession Index was also constructed, in which recessions were ranked with respect to their length, with a higher rank representing a longer recession. Every modification of the SRI is set to zero during expansion periods.

We then estimate a model similar to model (9) with different versions of the SRI as a dependent variable: 


$$
\begin{aligned}
\operatorname{Prob}\left(R_{t+k}=M \mid \Omega_{t}\right)= & N\left(c_{0}+c_{1} \text { CVI }_{t}+c_{2} A V G H R S_{t}+c_{3} V_{E N D O R_{t}}+\right. \\
& \left.+c_{4} \text { HOUSING }_{t}+c_{5} T R Y \text { STR }_{t}+c_{6} \text { SPRET }_{t}\right)
\end{aligned}
$$

where $M$ is one of the several values, taken on by the ordinal dependent variable SRI. The model is estimated by the ordered probit.

The estimation results indicate that an increase in the CVI is associated with an increase in the probability of a more severe recession three to six quarters ahead (Table 6). When recessions are ranked according to their length, the estimation results indicate that an increase in the CVI also raises the probability of having a longer recession (Table 6, bottom panel).

\section{Conclusions}

It has been long recognized that the financial conditions of the private sector may have significant influence on the macroeconomy. This paper shows that a combination of different factors-such as macroeconomic conditions, equity volatility, and structure of financial contracts, in addition to financial conditions-determines the health of the corporate sector, and has an impact on the entire economy. The Corporate Vulnerability Index (CVI) designed in this paper combines these factors - all of which are suggested by the structural theory of corporate debt.

The CVI is shown to predict economic recessions four to six quarters ahead. The results of the probit estimations indicate that an increase in the CVI is associated with a higher probability of a recession. The results also indicate that the model incorporating the CVI predicts recessions more successfully than other models - in fact, the timing of the 1990-91 recession was correctly predicted four quarters in advance, the recession episode that other models fail to predict. Moreover, the model with the CVI correctly predicted the timing of the current slowdown, which was missed by the model without the CVI.

Ordered probit estimates using the Severity of Recession Index, constructed in the paper, also indicate that an increase in the CVI is associated with a higher probability of having a more severe recession, both with regard to the loss of output and the recession length.

These results shed new light on the relationship between financial conditions of corporations and the macroeconomy, indicating that higher corporate vulnerability is indeed associated with a downturn. They also provide evidence in support of the structural theory of corporate debt, which suggested the combination of factors in explaining the vulnerability of the corporate sector. 


\section{DATA APPENDIX}

\section{Calculation of corporate interest payments}

Gross interest: each subtype of corporate market debt (dealer-placed commercial paper, municipal debt, corporate bonds, bank loans n.e.c. plus other nonbank loans, mortgages) is multiplied by a respective interest rate (see description of interest rate data below).

Net interest: gross interest after netting out receivables due to corporations. Annual data on net interest of nonfinancial corporations from the NIPA are converted to quarterly data using a cubic spline with the last observation matched to the source data. The data for 2001 are calculated assuming a constant quarterly growth rate, equal to the average growth rate in 2000.

\section{Interest rate data}

All data are from the Federal Reserve Board (FRB), their construction is described in detail on the FRB's web-site. This appendix only describes changes to the time-series we needed to undertake due to data limitations.

Corporate yields: Moody's average (Baa-rated) bonds, with average maturity of 25 years. Moody's attempts to construct averages derived from bonds whose remaining lifetime is such that newly issued bonds of comparable maturity would be priced off of the 30 -year treasury benchmark. Even though callable bonds are included in the index, issues that are judged susceptible to early redemption are excluded. The construction of the average yields is described in the Moody's Weekly Credit Survey, Corporate Yield Average Guidelines.

Treasury yields: 30-year constant maturity treasury bonds would have been the closest match for the corporate yield data used. However, these data are only available starting in 1977 (see table below). Therefore, average data on treasury bonds which are neither due nor callable in less than ten years (treasury composite, with maturity over ten years) are used. Since this series ends in June 2000 , it is concatenated with observations calculated as an unweighted average of yields on 30-, 20-, and 10-year bonds. Unweighted averaging is used by the FRB in constructing the composite long-term bond. The constructed average series closely matches the Composite FRB index. For a construction of the constant maturity indexes, see FRB web page: http://www federalreserve.gov/releases $/ \mathrm{h} 15 /$ data $/ \mathrm{m} / \mathrm{tcm} 30 \mathrm{y} . \mathrm{txt}$

\begin{tabular}{|l|l|}
\hline Maturity & Availability, monthly data \\
\hline 30-year & $02: 1977-$ present \\
\hline 20-year & $04: 1953-12: 1986$ and 10:1993 - present \\
\hline 10-year & $04: 1953-$ present \\
\hline Composite (10-year and longer) & $01: 1925-06: 2000$ \\
\hline
\end{tabular}


Mortgage rate: available only after January 1971, thus is constructed as Moody's AAA corporate bond yield plus 0.76-an average difference between two series after 1971 .

Municipal bond rates: constructed following the methodology described in Hall (2001).

Corporate paper rate: for the sample Q1 1971-Q2 1997 historical data on three-month A2/P2 nonfinancial commercial paper rate is used. For the sample period 1969 Q1-1970 Q4 data are constructed as a sum of the three-month treasury-bill yield and 0.78 , an average paper-bill difference after 1971 Q1.

Bank lending rate: primary bank lending rate.

\section{List of variables}

\begin{tabular}{|c|c|c|}
\hline Variable name & Description & Source or Calculation \\
\hline ASSTANG & Tangible assets* & $\begin{array}{l}\text { Table B.102. Flow of Funds, Federal Reserve Board } \\
\text { (FF, FRB) }\end{array}$ \\
\hline ASSTOT & Total assets & Table B.102 (FF, FRB) \\
\hline ASSFIN & Financial assets & Table F.102 (FF, FRB) \\
\hline LIABTOT & Total liabilities & Table F.102 (FF, FRB) \\
\hline DEBT & $\begin{array}{l}\text { Liabilities: Credit market debt } \\
\text { (Debt) }\end{array}$ & Table F.102 (FF, FRB) \\
\hline EQUITY & $\begin{array}{l}\text { Market value of equities } \\
\text { outstanding (Equity) }\end{array}$ & (FF, FRB) \\
\hline PROFITS & Profits with IVA and CCA & NIPA \\
\hline LEVFIN & Leverage & Credit Market Debt/ Financial Assets \\
\hline DBTEQTY & Balance sheet leverage & $\begin{array}{l}\text { Debt/(Debt+Equity). } \\
\text { Book value of debt and market value of equity }\end{array}$ \\
\hline DBTASS & Leverage & $\begin{array}{l}\text { Debt/Assets. Book value of debt and book value of } \\
\text { assets }\end{array}$ \\
\hline DBTTANG & Leverage & $\begin{array}{l}\text { Debt/Tangible Assets. Book value of dcbt and book } \\
\text { value of assets }\end{array}$ \\
\hline DBTFIN & Leverage & $\begin{array}{l}\text { Debt/ Financial Assets. Book value of debt and book } \\
\text { value of assets }\end{array}$ \\
\hline GRSINTR & Estimated gross interest, flow & $\begin{array}{l}\text { Estimated as described above. Composition of } \\
\text { liabilities: Flow of Funds, Federal Reserve Board } \\
\text { Interest Rates: FRB data and estimation, following } \\
\text { Hall (2001) (see above). }\end{array}$ \\
\hline NETINTR & Estimated net interest, flow & $\begin{array}{l}\text { Net interest of nonfinancial corporations, annual data, } \\
\text { NIPA } \\
\text { Converted to quarterly using cubic spline with last } \\
\text { observation matched to the source data. The data for } \\
2001 \text { are calculated using assuming a constant } \\
\text { quarterly growth rate, equal to average growth rate in } \\
2000 \text {. }\end{array}$ \\
\hline
\end{tabular}




\begin{tabular}{|c|c|c|}
\hline GRSBDN & $\begin{array}{l}\text { Estimated gross interest burden, } \\
\text { flow }\end{array}$ & $\begin{array}{l}\text { Gross interest divided by profits of nonfinancial } \\
\text { corporate sector inventory adjustment (IVA) and } \\
\text { capital consumption adjustment (CCA), NIPA }\end{array}$ \\
\hline NETBDN & Estimated net interest burden, flow & $\begin{array}{l}\text { Net interest divided by profits with IVA and CCA, } \\
\text { NIPA }\end{array}$ \\
\hline GRNNTSTOCK & Implied gross interest, stock & $\begin{array}{l}\text { Estimated as present value assuming constant } \\
\text { quarterly flows, equal to estimated gross interest, } \\
\text { during next } 25 \text { years to maturity. Discount rate set to } \\
\text { the current average corporate bond yield. }\end{array}$ \\
\hline NETINTSTOCK & Implied net interest burden stock & Above procedure is applied to NETINTR \\
\hline PROFSTOCK & Implied stock of profits & $\begin{array}{l}\text { Above procedure is applied to quarterly flows of } \\
\text { profits of nonfinancial corporations. Profits with IVA } \\
\text { and CCA, from NIPA. }\end{array}$ \\
\hline BRDGRSSTK & Stock gross interest burden & Implied stock gross interest / implied stock profits \\
\hline BRDNETSTK & Stock net interest burden & Implied stock net interest / implied stock profits \\
\hline TRYLONG & $\begin{array}{l}\text { Estimated average yield on long } \\
\text { treasury bonds }\end{array}$ & $\begin{array}{l}\text { Unweighted average of constant maturity } 10,20 \text {, and } \\
30 \text { Treasury bonds, FRB }\end{array}$ \\
\hline TRYCOMP & $\begin{array}{l}\text { Average composite yield on } \\
\text { Treasury bonds with } 10 \text { or more } \\
\text { years to maturity }\end{array}$ & FRB \\
\hline Y_BAA & Yield on Moody's Baa bonds & FRB \\
\hline STDDEVSP & $\begin{array}{l}\text { Standard deviation of S\&P } 500 \\
\text { return }\end{array}$ & $\begin{array}{l}\text { Rolling standard deviation, 12-quarter window. } \\
\text { Haver Analytics }\end{array}$ \\
\hline STDEVWIL & $\begin{array}{l}\text { Standard deviation, Wilshire } 5000 \\
\text { (available from } 1971 \text { only) }\end{array}$ & $\begin{array}{l}\text { Rolling standard deviation, 12-quarter window. } \\
\text { Haver Analytics }\end{array}$ \\
\hline AVRHRS & $\begin{array}{l}\text { Average weekly hours, } \\
\text { manufacturing }\end{array}$ & Haver Analytics \\
\hline VENDOR & $\begin{array}{l}\text { Vendor performance, slower } \\
\text { deliveries diffusion index, percent }\end{array}$ & Haver Analytics \\
\hline HOUSING & $\begin{array}{l}\text { New private housing unites } \\
\text { authorized by local building } \\
\text { permits (thousands, SAAR) }\end{array}$ & Haver Analytics \\
\hline TRY_STR & $\begin{array}{l}\text { Treasury yield curve: } 10 \text {-year } \\
\text { Treasury bond less Fed funds rates } \\
\text { (percent) }\end{array}$ & Haver Analytics \\
\hline SPRET & $\begin{array}{l}\text { Stock price return: S\&P } 500 \\
\text { Composite }\end{array}$ & $\begin{array}{l}\text { Estimated as } R_{t}=\ln I_{t}-\ln I_{t-1} \text {, where } I_{t} \text { is the value of } \\
\text { S\&P500 Composite stock index. Haver Analytics }\end{array}$ \\
\hline
\end{tabular}

* All data, except for interest rates, bond yields, and stock returns, are for nonfinancial corporate business. 
Table 1. Sample Summary Statistics: Selected Variables 1/

\begin{tabular}{lrr}
\hline & Mean & Standard Deviation \\
\hline Balance sheet leverage & & \\
Debt burden & 53.77 & 9.51 \\
Total leverage & 108.76 & 46.30 \\
Nominal corporate bond yield & 147.01 & 50.61 \\
Real corporate bond yield & 10.03 & 2.38 \\
\end{tabular}

1/ In percent.

Table 2. Model Fit to Corporate Yields 1/

\begin{tabular}{lrc}
\hline & Mean & Standard Deviation \\
\hline Corporate yields: & & \\
Nominal actual & 10.028 & 2.210 \\
Nominal fitted & 10.031 & 2.384 \\
& & \\
Real actual & 6.799 & 2.447 \\
Real fitted & 6.924 & 2.726 \\
Root Mean Squared Error (RMSE): & & \\
Nominal, absolute value & 0.966 & 0.112 \\
$\quad$ As percent of nominal actual mean & 9.636 & \\
Real, absolute value & 0.967 & 0.189 \\
$\quad$ As a percent of real actual mean & 13.959 & \\
\end{tabular}

$1 /$ In percent

Table 3. Estimation Results of Fitting the Model to Corporate Yield Data 1/

The model estimated is: $y_{t}=C O N S T+y_{t}\left(L E V E R_{t} r_{t} A \sigma_{t} B C O S T, T H E T A, B B E T A\right)+u_{t}$, where $y_{t}$ is a yield on a long-maturity Corporate Bond Index; $y_{t}($ ) is a theoretical corporate bond yield, derived in Anderson, Sundaresan, and Tycon (1996); LEVER, is a measure of total leverage, $r_{r}$ is a yield on a long-maturity Treasury Composite Bond Index, and $S I G M A_{i}$ is equity volatility. CONST, a volatility scaling factor $A$, a bankruptcy cost $B C O S T$, and a dividend rate $B B E T A$ are constant model parameters. $\mathfrak{u}_{\mathrm{t}}$ is a residual. The model is estimated by non-linear least squares over the sample from $1969 \mathrm{Q} 1$ to $2001 \mathrm{Q} 4$.

\begin{tabular}{lrrrrrr}
\hline & \multicolumn{2}{c}{ Nominal Yields } & & \multicolumn{2}{c}{ Real Yields } \\
\cline { 2 - 3 } \cline { 6 - 7 } & Coefficient 1/ & $\begin{array}{r}\text { Standard } \\
\text { Error }\end{array}$ & & Coefficient 1/ & $\begin{array}{r}\text { Standard } \\
\text { Error }\end{array}$ \\
\hline & & & & & \\
CONST & 14.352 & 0.204 & & 10.944 & 0.188 \\
THETA & 2.004 & 0.103 & & 4.134 & 0.188 \\
BCOST & 6.982 & 0.414 & & 10.699 & 0.568 \\
A & 0.099 & 0.000 & & 0.178 & 0.001 \\
BBETA & 27.599 & 0.018 & & 20.044 & 0.037
\end{tabular}

Adj. R-squared $=0.823 \quad$ Adj. R-squared $=0.849$

1/ Coefficient significant at a 1 percent level. 
Table 4. Predicting the Probability of Recession, Probit Estimations

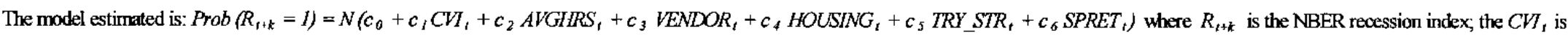
the Corporate Vulnerability Index; $A V G H R S_{1}$ is average weekly hours worked; VENDOR, is the vendor performance index; HOUSING, is housing starts; TRY STR, is the Treasury yield curve; and $S P R E T_{t}$ is stock returns. N..) is a curmulative normal distribution function. $k$ is a forecasting horizon, in quarters.

\begin{tabular}{|c|c|c|c|c|c|c|c|c|c|c|c|c|c|c|}
\hline & \multicolumn{2}{|c|}{$k=0$} & \multicolumn{2}{|c|}{$k=1$} & \multicolumn{2}{|c|}{$k=2$} & \multicolumn{2}{|c|}{$k=3$} & \multicolumn{2}{|c|}{$k=4$} & \multicolumn{2}{|c|}{$k=5$} & \multicolumn{2}{|c|}{$k=6$} \\
\hline & Coef. & Std Err. & Coef. & Std. Err. & Coef. & Std. Err. & Coef. & Std Err. & Coef. & Std. Err. & Coef. & Std Err. & Coef. & Sid Err. \\
\hline$c_{1}$ & -1.216 & 0.911 & -1.060 & 1.173 & 0.716 & 1.398 & $1.6493 /$ & 1.017 & $3.0341 /$ & 1.066 & $1.6163 /$ & 0.895 & $2.1653 /$ & 1.022 \\
\hline$c_{2}$ & $-1.5391 /$ & 0.341 & $-0.900 \mathrm{l} /$ & 0.308 & 0.102 & 0.314 & 0.278 & 0.273 & $0.5351 /$ & 0.289 & $1.6092 /$ & 0.726 & 0.276 & 0.375 \\
\hline$c_{3}$ & -0.001 & 0.021 & -0.005 & 0.020 & 0.022 & 0.022 & 0.027 & 0.017 & 0.034 & 0.021 & -0.041 & 0.028 & -0.003 & 0.018 \\
\hline$c_{4}$ & $-0.0021 /$ & 0.001 & $-0.002 \mathrm{l} /$ & 0.001 & -0.0022 & 0.001 & -0.001 & 0.001 & 0.001 & 0.001 & 0.000 & 0.001 & $0.0031 /$ & 0.001 \\
\hline$c_{s}$ & 0.007 & 0.071 & $-0.2423 /$ & 0.109 & $-0.441 \mathrm{l} /$ & 0.108 & $-0.5011 /$ & 0.125 & $-0.613 \mathrm{l} /$ & 0.131 & $0.3092 /$ & 0.121 & $-0.6711 /$ & 0.137 \\
\hline$c_{6}$ & -6.799 & 2.976 & $-17.2011 /$ & 4.545 & $-11.5131 /$ & 4.159 & -5.796 & 4.093 & -2.998 & 3.628 & -2.458 & 2.647 & 3.981 & 3.703 \\
\hline$c_{\theta}$ & $63.6971 /$ & 13.537 & $39.099 \mathrm{~V} /$ & 12.392 & -4.061 & 13.271 & -13.74 & 11.118 & $-27.162 /$ & 12.026 & -0.443 & 1.151 & -17.646 & 16.134 \\
\hline Pseudo R2 & 0.476 & & 0.602 & & 0.567 & & 0.478 & & 0.466 & & 0.208 & & 0.282 & \\
\hline
\end{tabular}

$1 /$ Coefficient siguificart at a 1 percent level

$2 /$ Coefficient significant at a 5 percent level.

$3 /$ Coefficient significant at a 10 percent level. 
Table 5. The Severity of Recession Indices

\begin{tabular}{|c|c|c|c|c|c|c|c|}
\hline Recessions & $\begin{array}{l}\text { Real GDP } \\
\text { Decline, } \\
\text { Cumulative } \\
\text { (percent) }\end{array}$ & $\begin{array}{l}\text { Length } \\
\text { Quarter }\end{array}$ & $\begin{array}{l}\text { Real GDP } \\
\text { Decline per } \\
\text { Quarter } \\
\text { (percent) }\end{array}$ & $\begin{array}{c}\text { Rating } \\
\text { Individual * }\end{array}$ & $\begin{array}{l}\text { Rating: } \\
\text { Grouped \#1** }\end{array}$ & $\begin{array}{l}\text { Rating: } \\
\text { Grouped } \# 2^{* * *}\end{array}$ & $\begin{array}{l}\text { Rating: } \\
\text { Recession } \\
\text { Length }\end{array}$ \\
\hline Q3 1953 - Q2 1954 & 2.570 & 4 & 0.643 & 5 & 3 & 2 & 3 \\
\hline Q4 1957 - Q2 1958 & 4.170 & 3 & 1.390 & 7 & 4 & 3 & 2 \\
\hline Q3 1960 - Q2 1961 & 0.710 & 3 & 0.237 & 2 & 2 & 1 & 2 \\
\hline Q1 1970 - Q4 1970 & 0.140 & 4 & 0.035 & 1 & 1 & 1 & 3 \\
\hline Q1 1974 - Q1 1975 & 2.735 & 5 & 0.547 & 4 & 3 & 2 & 4 \\
\hline Q2 $1980-$ Q3 1980 & 4.330 & 2 & 2.165 & 8 & 5 & 3 & 1 \\
\hline Q4 1981 - Q4 1982 & 2.244 & 5 & 0.449 & 3 & 2 & 2 & 4 \\
\hline Q4 1990-Q1 1991 & 2.622 & 2 & 1.311 & 6 & 4 & 2 & 1 \\
\hline Q2 2001 - Q4 2001*** & 0.265 & 3 & 0.088 & 1 & 1 & 1 & 2 \\
\hline
\end{tabular}

* Rated according to a decline per quarter.

** Grouped according to a total cumulative real decline during a recession:

$\begin{array}{cl}\text { Rating } & \text { Cumulative } \\ 1 & 0-0.1 \\ 2 & 0.1-0.5 \\ 3 & 0.5-1.0 \\ 4 & 1.0-1.5 \\ 5 & >1.5\end{array}$

*** Grouped according to a cumulative real decline: 1 - light; 2 - average; 3 - severe.

*** The NBER's Business Cycle Dating Comrnittee has determined that the recession began in the U.S. economy in March 2001. The recession trough has not been defined yet, as of December 7, 2002. 
Table 6. Predicting the Severity of Recessions, Ordered Probit Estimations

The model estimated is: $\operatorname{Prob}\left(R_{t-k}=M\right)=N\left(c_{0}+c_{1} C_{1} V I_{t}+c_{2}\right.$ AVGHRS $+c_{3}$ VENDOR $+c_{4}$ HOUSING $_{t}+c_{s}$ $T R Y S T R t+c_{6} S P R E T$, )

where $\mathrm{R}_{\mathrm{t+k}}$ is the NBER recession index, $M$ is one of the Severity of Recession Index (SRI) modifications from Table 5; the CVI, is the Corporate Vulnerability Index, $A V G H R S_{t}$ is average weekly hours worked, VENDOR, is the vendor performance index, HOUSING, is housing starts, TRY STR, is the Treasury yield curve, and SPRET is stock returns. N(.) is a cumulative normal distribution function. $k$ is a forecasting horizon, in quarters.

\begin{tabular}{|c|c|c|c|c|c|c|}
\hline \multirow{2}{*}{ SRI, Rating: Individual } & \multicolumn{2}{|c|}{$k=3$} & \multicolumn{2}{|c|}{$k=4$} & \multicolumn{2}{|c|}{$k=6$} \\
\hline & & & & & & \\
\hline & Coefficient & Std. Lrror & Coefficient & Std. Eтror & Coenlicient & Std. Error \\
\hline$c_{1}$ & $1.248 * *$ & 0.665 & $1.939 *$ & 0.731 & $1.598^{*}$ & 0.626 \\
\hline$c_{2}$ & 0.122 & 0.223 & 0.160 & 0.255 & 0.170 & 0.293 \\
\hline$c_{3}$ & 0.015 & 0.014 & 0.022 & 0.017 & 0.000 & 0.016 \\
\hline$c_{4}$ & -0.000 & 0.001 & $0.001 * *$ & 0.001 & $0.003^{*}$ & 0.001 \\
\hline$c_{5}$ & $-0.447^{*}$ & 0.098 & $-0.489^{*}$ & 0.098 & $-0.571^{*}$ & 0.091 \\
\hline$c_{\sigma}$ & -4.630 & 3.324 & -2.359 & 2.715 & 3.595 & 3.523 \\
\hline Pseudo RZ & 0.282 & & 0.271 & & 0.236 & \\
\hline
\end{tabular}

\begin{tabular}{|c|c|c|c|c|c|c|}
\hline \multicolumn{7}{|l|}{ SRI, Rating: Groupped \# 1} \\
\hline & Coefficient & Std. Error & Coefficient & Std. Etror & Coefficient & Std. Error \\
\hline$c_{1}$ & $1.323^{* *}$ & 0.655 & $1.970^{*}$ & 0.728 & $1.798^{*}$ & 0.673 \\
\hline$c_{2}$ & 0.084 & 0.223 & 0.142 & 0.258 & 0.182 & 0.290 \\
\hline$c_{3}$ & 0.016 & 0.014 & 0.022 & 0.017 & 0.000 & 0.016 \\
\hline$c_{4}$ & 0.000 & 0.001 & $0.001 *$ & 0.001 & $0.003^{*}$ & 0.001 \\
\hline$c_{5}$ & $-0.440^{*}$ & 0.097 & $-0.482 *$ & 0.098 & $-0.566 *$ & 0.089 \\
\hline$c_{6}$ & -4.485 & 3.278 & -2.459 & 2.709 & 3.230 & 3.531 \\
\hline Pseudo R2 & 0.286 & & 0.271 & & 0.237 & \\
\hline
\end{tabular}

\begin{tabular}{|c|c|c|c|c|c|c|}
\hline \multicolumn{7}{|c|}{ SRI, Rating: Groupped \# 2} \\
\hline & Cocfficient & Std. Error & Coefficient & Std. Frror & Coefficient & Std. Lirror \\
\hline$c_{1}$ & $1.904^{*}$ & 0.774 & $2.576^{*}$ & 0.833 & $2.223^{*}$ & 0.733 \\
\hline$c_{2}$ & 0.080 & 0.245 & 0.150 & 0.286 & 0.157 & 0.313 \\
\hline$c_{3}$ & 0.016 & 0.014 & 0.026 & 0.015 & -0.002 & 0.017 \\
\hline$c_{4}$ & 0.000 & 0.001 & $0.001^{* *}$ & 0.001 & $0.003^{*}$ & 0.001 \\
\hline$c_{5}$ & $-0.487^{*}$ & 0.105 & $-0.536^{*}$ & 0.113 & $-0.605^{*}$ & 0.108 \\
\hline$c_{6}$ & -4.686 & 3.401 & -1.813 & 2.720 & 2.778 & 3.670 \\
\hline Pseudo R2 & 0.365 & & 0.374 & & 0.295 & \\
\hline \multicolumn{7}{|c|}{ SRI, Rating: Recession Length } \\
\hline & Coefficient & Std. Error & Coefficient & Stal. Enror & Cocllicient & Std. Error \\
\hline$c_{1}$ & $3.040^{*}$ & 0.932 & $4.516^{*}$ & 0.978 & $2.720^{*}$ & 1.017 \\
\hline$c_{2}$ & 0.245 & 0.295 & $0.691^{*}$ & 0.295 & 0.151 & 0.375 \\
\hline$c_{3}$ & $0.054^{*}$ & 0.017 & $0.056^{*}$ & 0.020 & -0.001 & 0.019 \\
\hline$c_{4}$ & 0.000 & 0.001 & 0.001 & 0.001 & $0.003^{*}$ & 0.001 \\
\hline$c_{5}$ & $-0.492^{*}$ & 0.125 & $-0.652 *$ & 0.152 & $-0.694^{*}$ & 0.145 \\
\hline$c_{6}$ & -5.795 & 4.181 & -2.702 & 3.520 & 3.612 & 3.767 \\
\hline Pseudo R2 & 0.416 & & 0.403 & & 0.308 & \\
\hline
\end{tabular}

* Coefficient significant at a I percent leyel; ** at a 5 percent level; ${ }^{* * *}$ at a 10 percent level 
Figure 1. P/E Ratios of S\&P 500 Composite Stock Index.

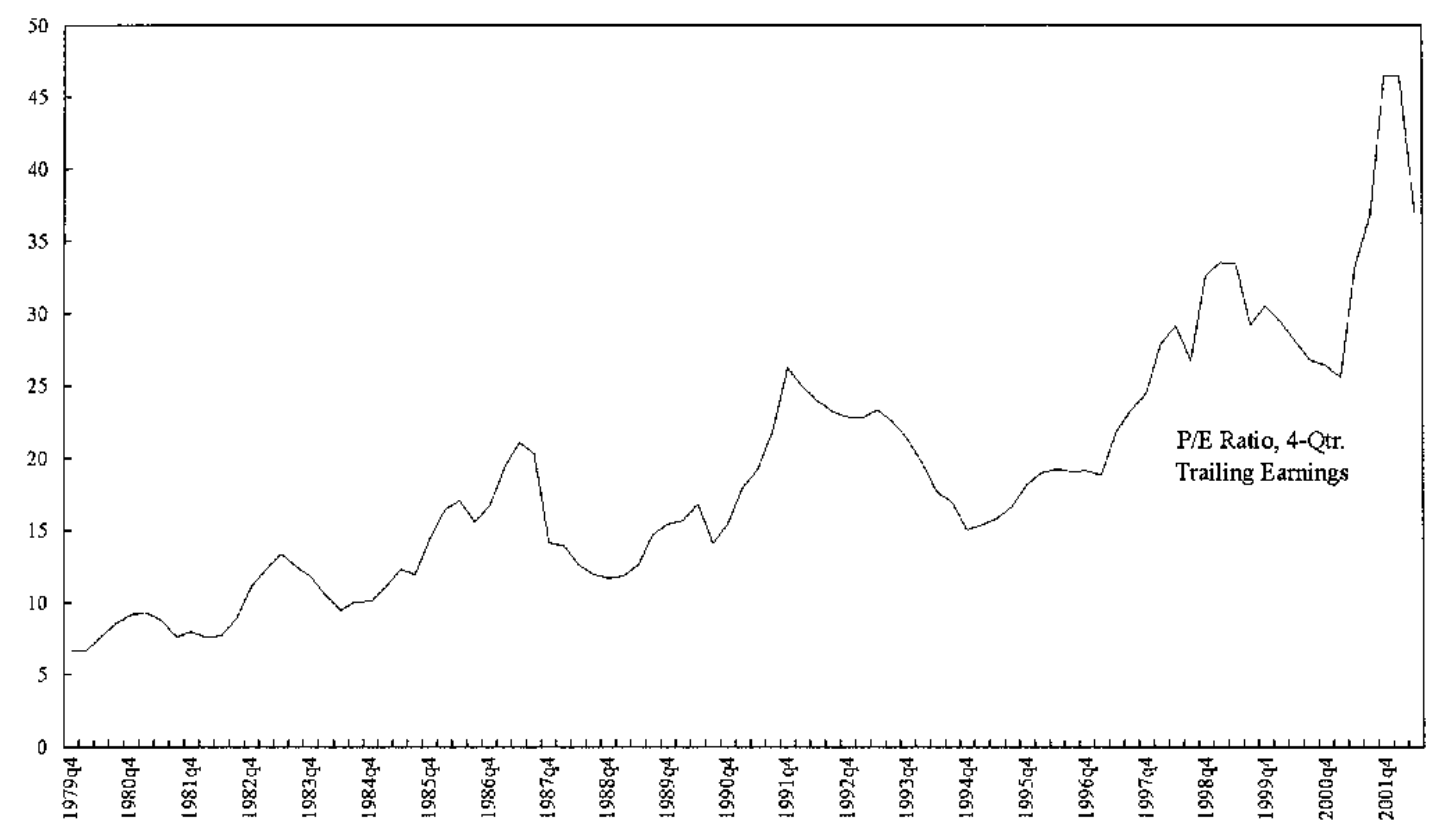
Source: Haver Analytics .

Figure 2. Corporate Sector: Total Leverage and Corporate Bond Spreads 1/

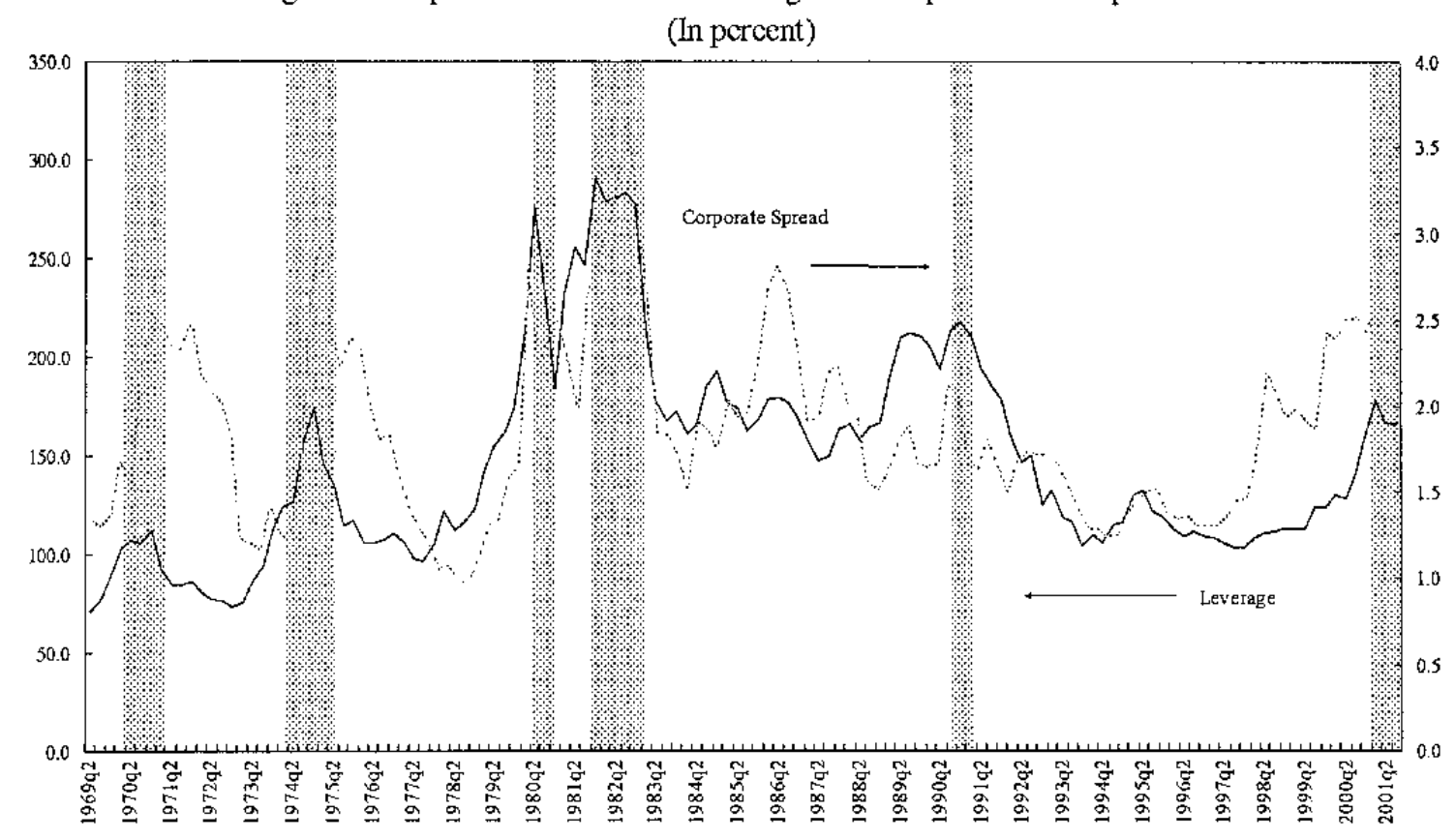


Figure 3. Corporate Sector: Total Leverage 1/

(In percent)

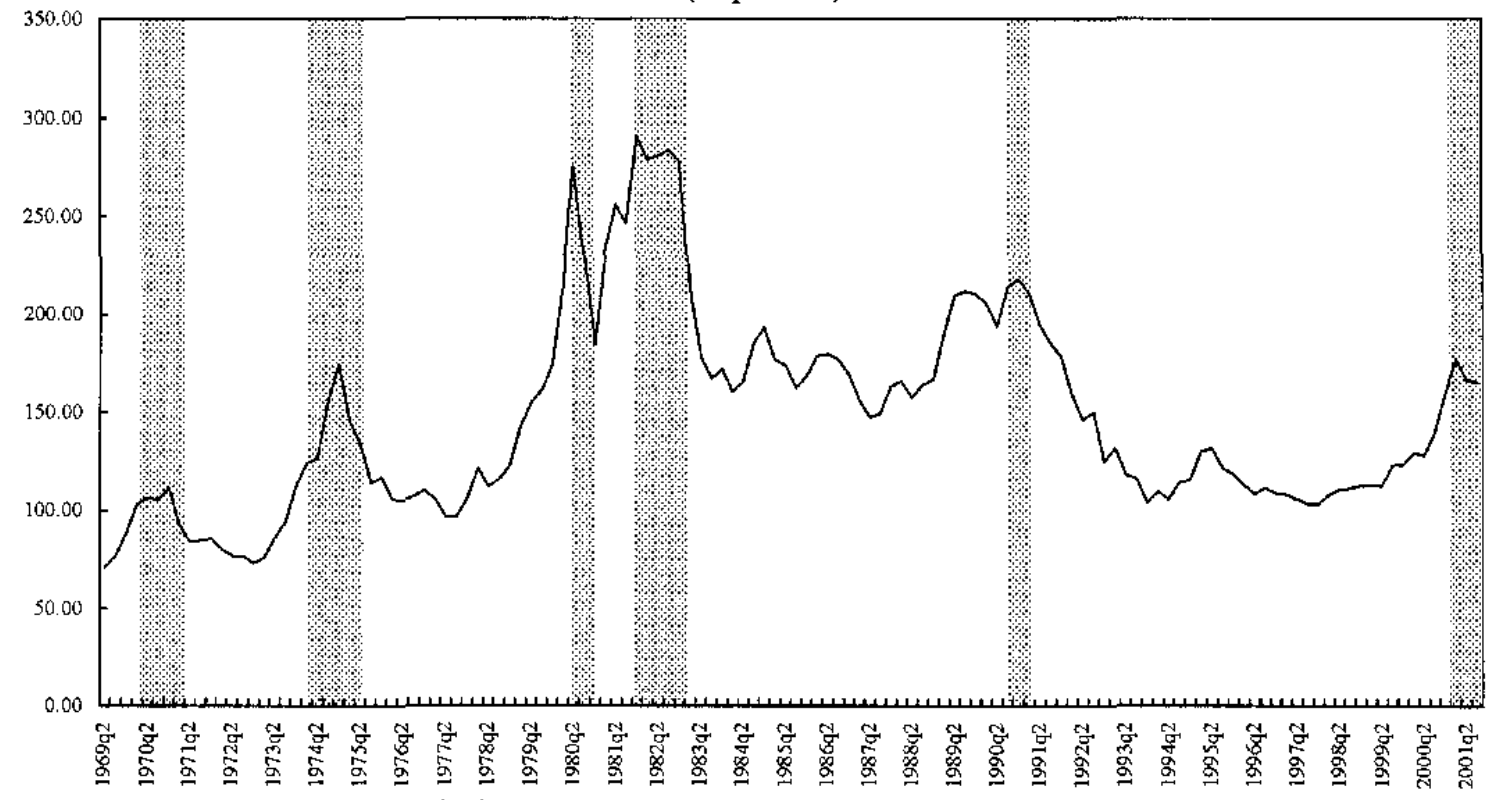

Source: Board of Governors of the Federal Reserve, Flow of Funds Accounts of the United States, and author's estimates.

1/ The Total Leverage is defined as a sum of balance sheet leverage and a slock of gross debt burdon. Shaded areas indicate recession periods.

Figure 4. Nonfarm Nonfinancial Corporate Sector: Funds Raised, \$ billions

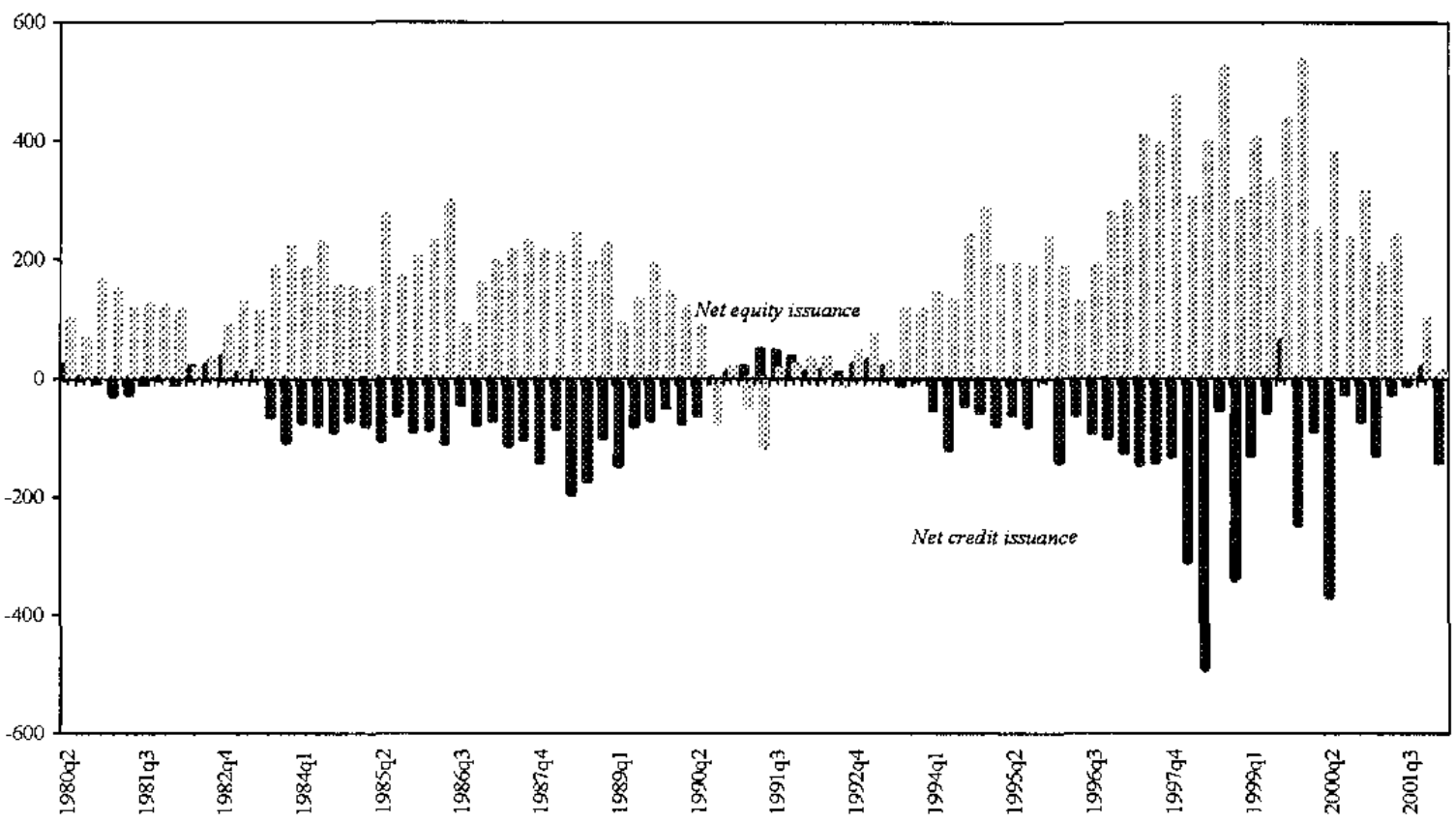

Source: Board of Governors of the Federal Reserve, Flow of Funds Accounts of the United States. 
Figure 5. Nominal Corporate Bond Yields: Actual and Fitted (In percent)

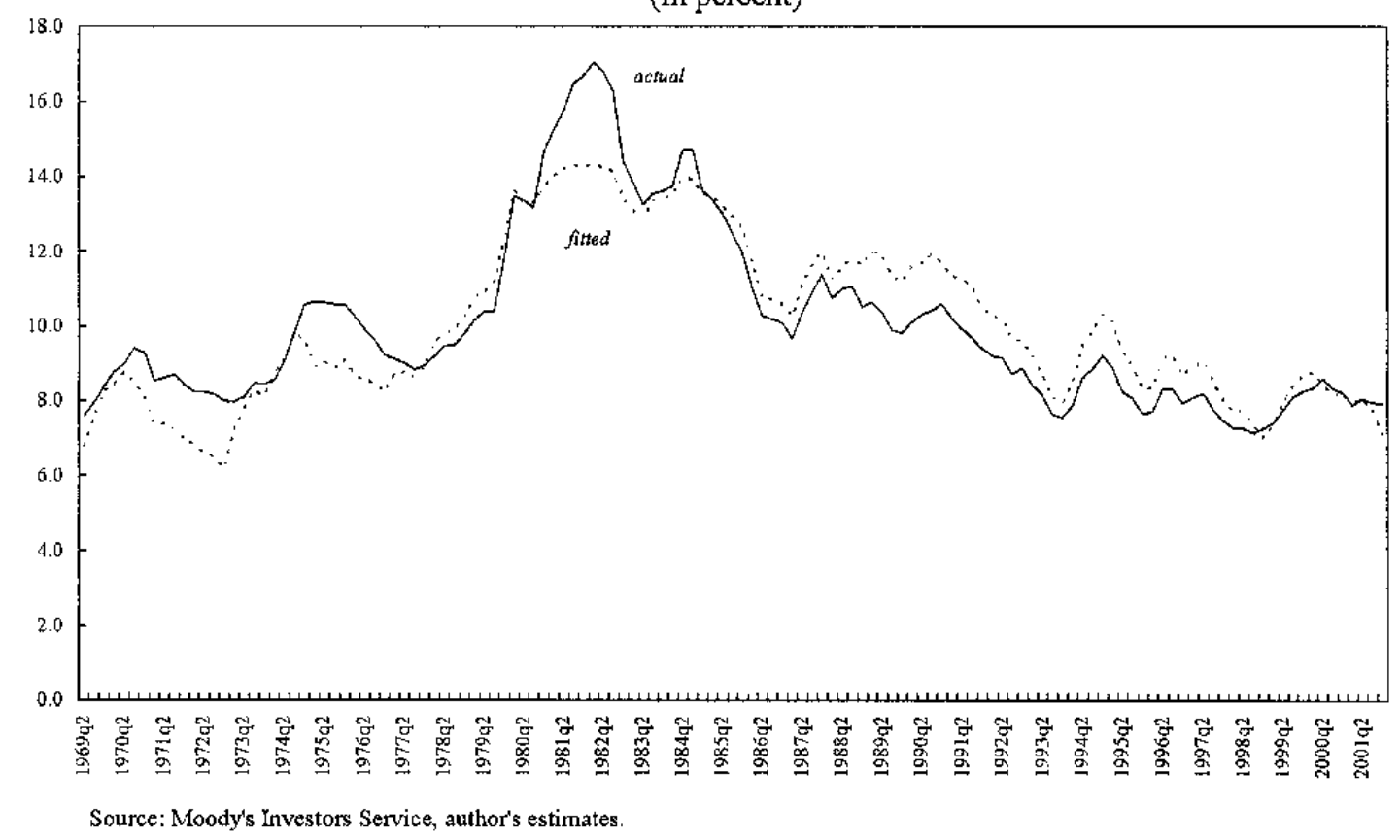

Figure 6. Real Corporate Bond Yields: Actual and Fitted (In percent)

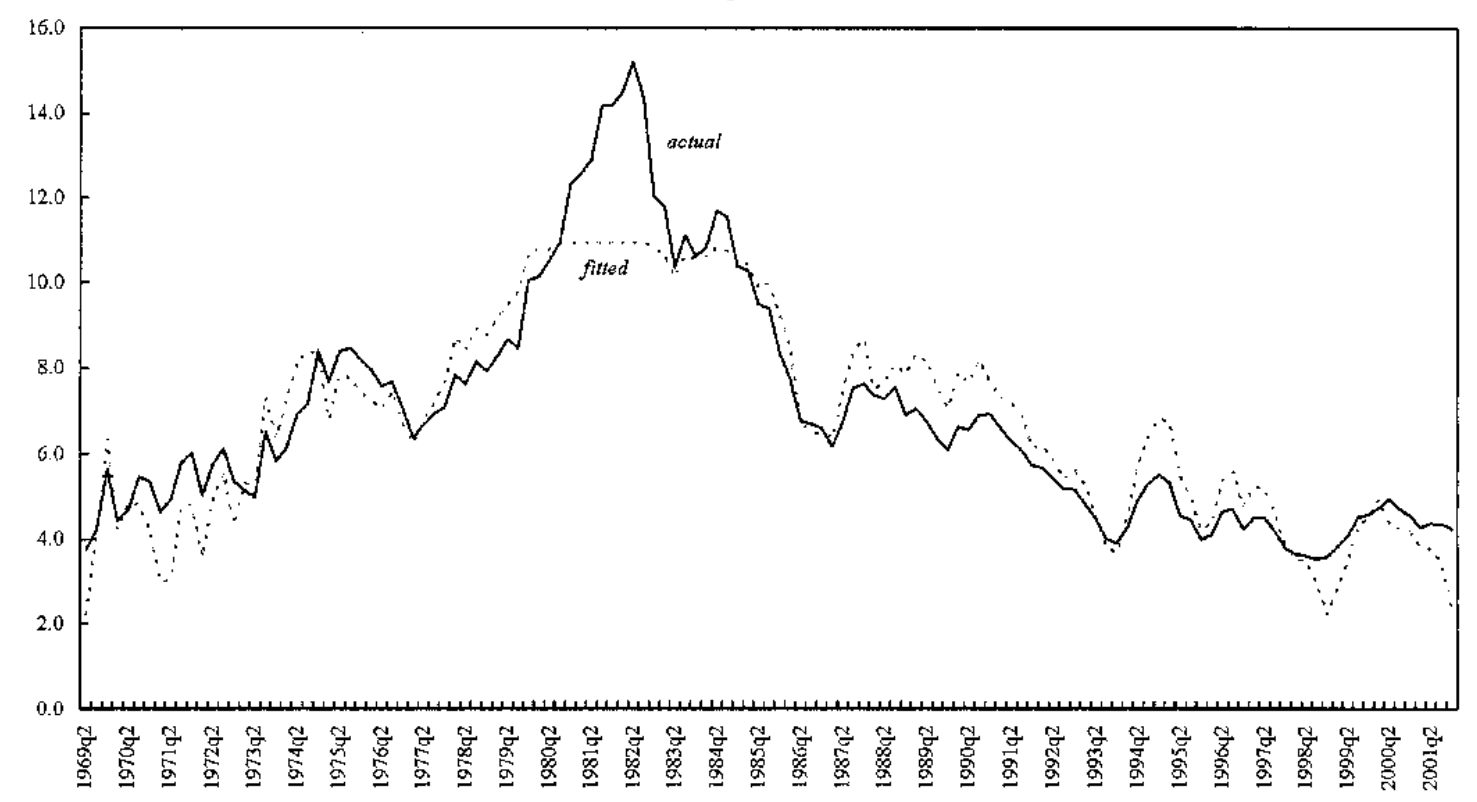
Source: Moody's Investors Service, author's estimates. 
Figure 7. Corporate Vulnerability Index 1/

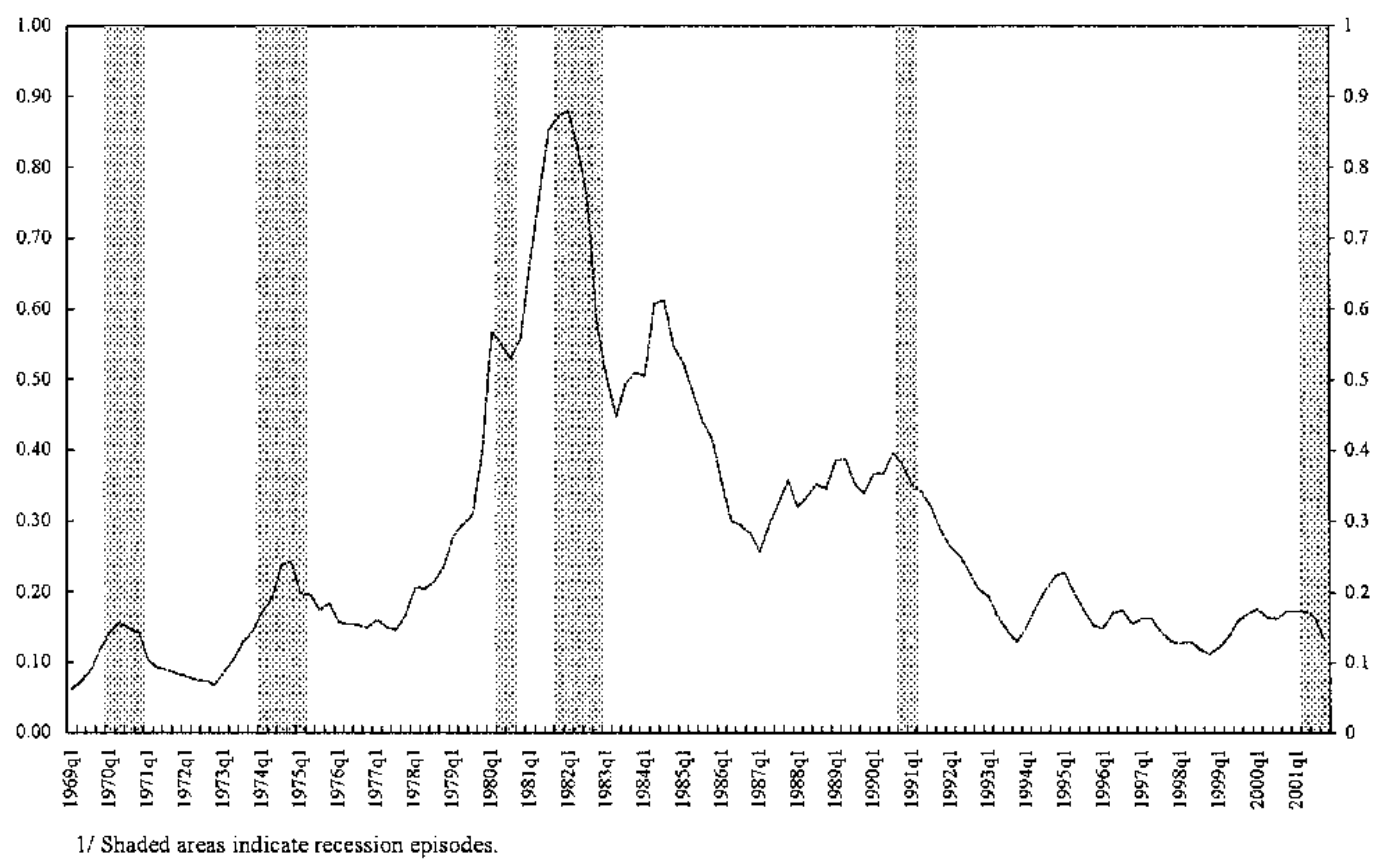

Figure 8. Probability of Recession, Predicted with the Corporate Vulnerability Index 1/

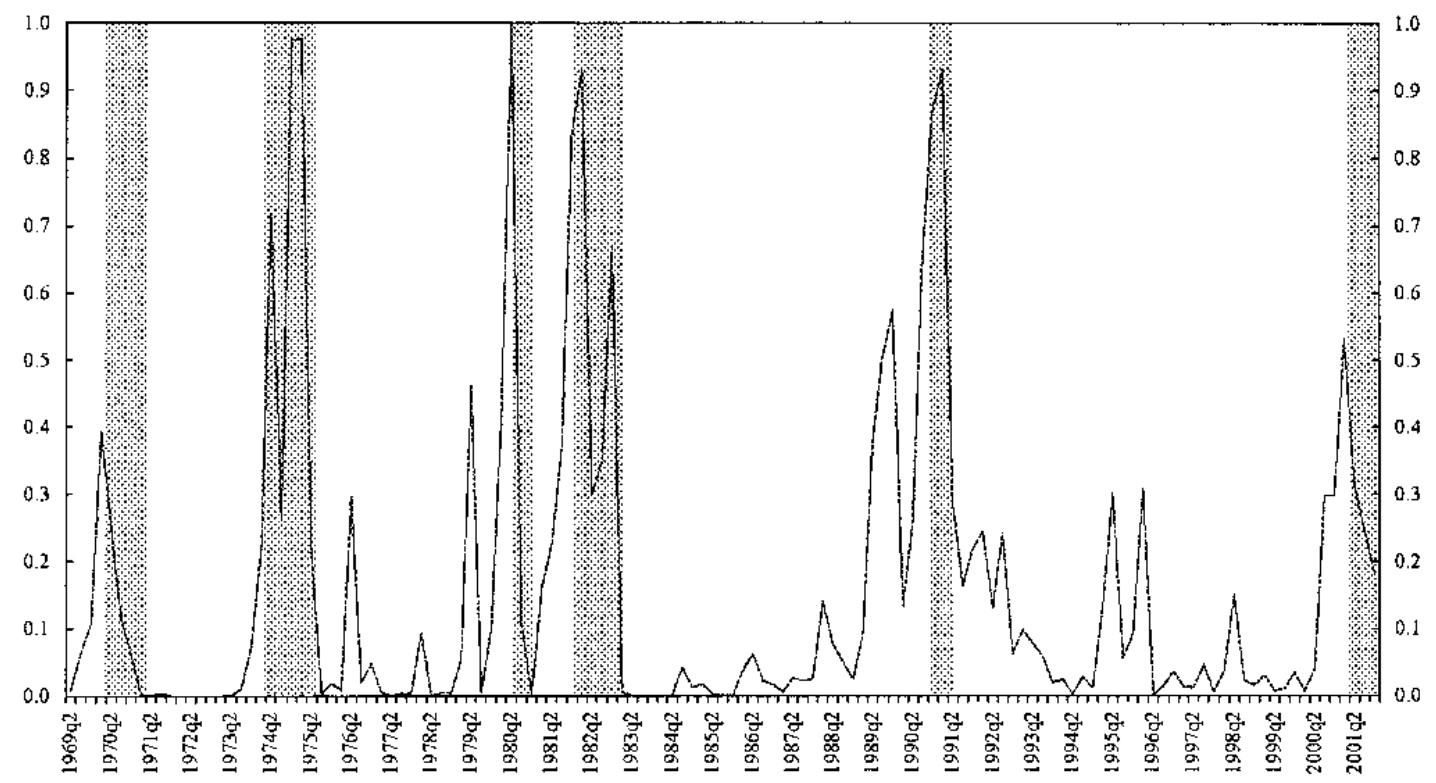

1/ Shaded areas indicate recession episodes. 
Figure 9. Probability of Recession, Predicted without the Corporate Vulnerability Index $1 /$

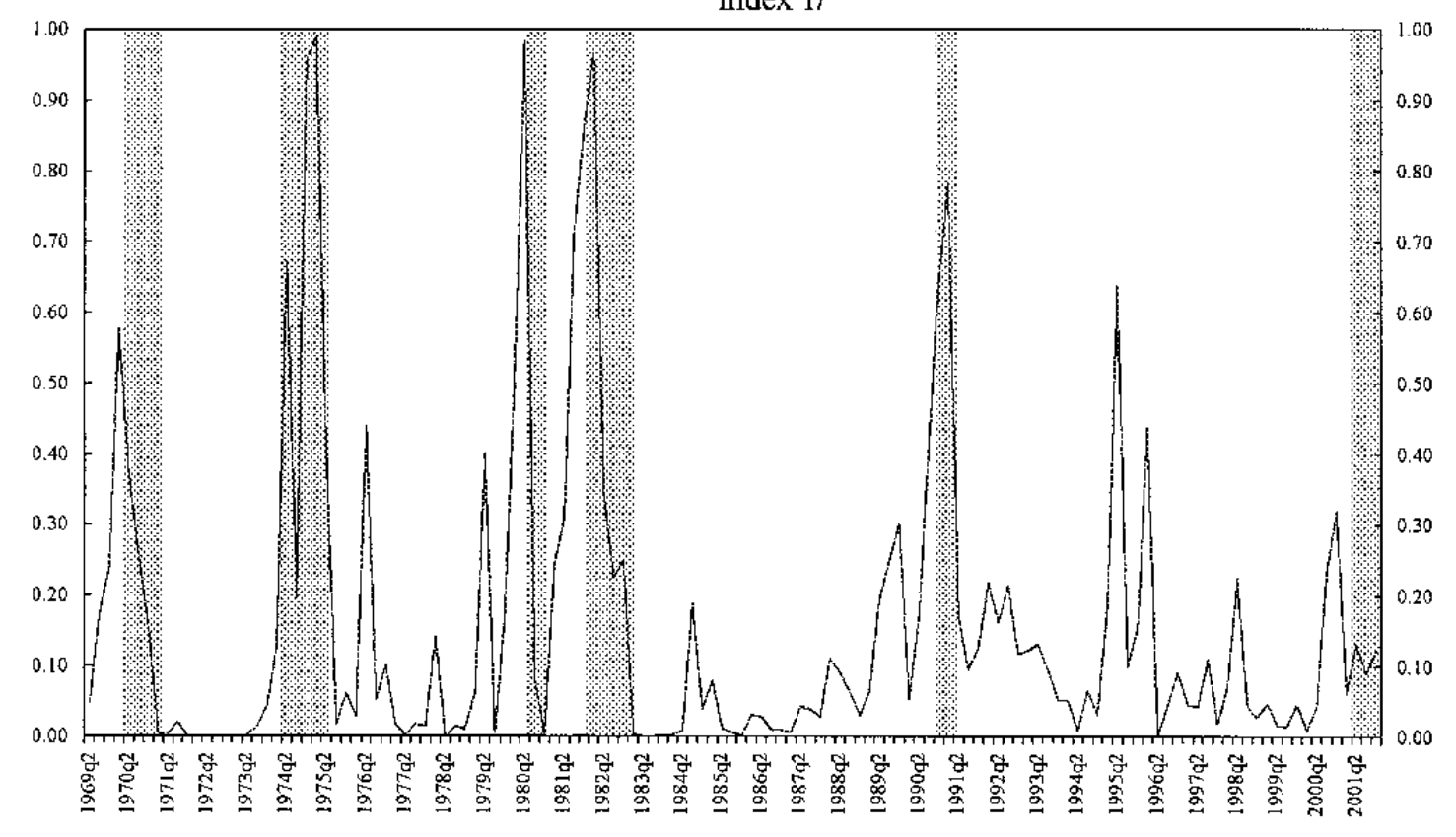

1/ Shaded areas indicate recession episodes 


\section{References}

Andersen, Torben, Tim Bollerslev, Francis X. Diebold, and Paul Labys, 2002, "Modeling and Forecasting Realized Volatility," NBER Working Paper No. 8160 (Cambridge, Massachusetts: National Bureau of Economic Research).

Anderson, Ronald, and Suresh Sundaresan, 1996, "Design and Valuation of Debt Contracts," Review of Financial Studies, Vol. 9, pp. 37-68.

2000, "A Comparative Study of Structural Models of Corporate Bond Yields: An Exploratory Investigation," Journal of Banking And Finance Vol. 24, pp. 255-69.

and Pierre Tychon, 1996, "Strategic Analysis of Contingent Claims," European Economic Review, Vol. 40, pp. 871-881.

Bernanke, Ben, 1983, "Non-Monetary Effects of the Financial Crisis in the Propagation of the Great Depression," American Economic Review 73, pp. 257-76.

and Mark Gertler, 1986, "Agency Costs, Collateral, and Business Fluctuations," NBER Working Paper No. 2015 (Cambridge, Massachusetts: National Bureau of Economic Research).

,1990, "Financial Fragility and Economic Performance," Quarterly Journal of Economics Vol. 105, pp. 87-114.

, 1995, "Inside the Black Box: The Credit Channel of Monetary Policy Transmission," Journal of Economic Perspectives 9, pp. 27-48.

, and Simon Gilchrist, 1996, "The Financial Accelerator and the Flight to Quality," Review of Economics and Statistics Vol. 78, pp. 1-15.

Bernanke, Ben, and Cara Lown, "The Credit Crunch," Brookings Papers on Economics Activity: Brookings Institute 2, pp. 205-239.

Black, Fisher, and Myers Scholes, 1973, "The Pricing of Options And Corporate Liabilities," Journal of Political Economy, Vol. 81, pp. 637-659.

Carlstrom, Charles T., and Timothy S. Fuerst, 1997, "Agency Costs, Net Worth And Business Fluctuations: A Computable General Equilibrium Analysis," American Economic Review, Vol. 87, pp. 893-910.

Chan-Lau, Jorge, and Iryna Ivaschenko, 2001, "Corporate Bond Risk and Real Activity: An Empirical Analysis of Yield Spreads and Their Systematic Components," Working Paper No. 01/158 (Washington: International Monetary Fund). 
Cookson, Richard, 2001, "Corporate Finance," Economist, January 27.

Delianedis, Gordon, and Robert Geske, 1999, "Credit Risk and Risk-Neutral Default Probabilities: Information about Rating Migrations and Defaults," Working Paper, (Los Angeles: UCLA).

Dotsey, Michael, 1998, "The Predictive Content of the Interest rate Term Spread for Future Economic Growth," Federal Reserve Bank of Richmond, Economic Quarterly, Vol. 84, pp. 31-51.

Dueker, Michael, 1997, "Strengthening the Case for the Yield Curve as a Predictor of U.S. Recessions," Federal Bank of St. Louis Review, March/April, pp. 41-51.

Duffee, Gregory R., 1998, "The Relation Between Treasury Yields and Corporate Yield Spreads," Journal of Finance, Vol. 53, pp. 2225-2243.

Duffie, Darrell, and Kenneth Singleton, 1996, "Modeling Term Structures of Defaultable Bonds" Review of Financial Studies, Vol. 12, pp. 687-720.

Eberhart, Allan, William T. Moore, and Rodney L. Roenfeldt, 1990, "Security Pricing and Deviations from the Absolute Priority Rule in Bankruptcy Proceedings," Journal of Finance, Vol. 45, pp. 1457-1469.

Elton, Edwin J., Martin J. Gruber, Deepak Agrawal, and Christopher Mann, 2001, "Explaining the Rate Spread on Corporate Bonds," Journal of Finance, Vol. 56, pp. 247-77.

Eom, Young Ho, Jean Helwege, and Jing-zhi Huang, 2002 "Structural Models of Corporate Bond Pricing: An Empirical Analysis," Unpublished, http://www.defaultrisk.com.

Estrella, Arturo, and Gikas Hardouvelis, 1991, "The Term Structure as a Predictor of Real Economic Activity," Journal of Finance, Vol. 46, pp. 555-576.

Estrella, Arturo, and Frederic Mishkin, 1997, "Predicting U.S. Recessions: Financial Variables as Leading Indicators," Review of Economics and Statistics, Vol. 80, pp. 45-61.

Ericsson, Jan, and Joel Reneby, (1998), "A Framework for Valuing Corporate Securities," Applied Mathematical Finance, Vol. 5, pp. 143-163.

Franks, Julian, and Walter Torous, 1989, "An Empirical Investigation of U.S. Firms in Reorganization," Journal of Finance, Vol. 44, pp. 747-769. 
Franks, Julian, and Walter Torous, 1994, "Comparison of Financial Reconstructing in Distressed Exchanges and Chapter 11 Reorganizations," Journal of Financial Economics, Vol. 35, pp. 349-370.

Fisher, Lawrence, 1959, "Determinants of Risk Premiums on Corporate Bonds," Journal of Political Economy, Vol. 67, pp. 217-237.

Geske, Robert, 1977, "The Valuation of Corporate Liabilities as Compound Options," Journal of Financial and Quantitative Analysis, Vol. 12, pp. 541-552.

Gilchrist, Simon, and Charles P. Himmelberg, 1995, "Evidence on the Role of Cash Flow for Investment," Journal of Monetary Economics, Vol. 36, pp. 541-572.

Greenspan, Alan, 2002, Testimony of Chairman Alan Greenspan Federal Reserve Board's Semiannual Monetary Policy Report to The Congress Before the Committee on Financial Services, U.S. House of Representatives, February 27.

Hall, Robert, 2001, "The Stock Market and Capital Accumulation," Hoover Institution (Stanford: Stanford University).

Hoshi, Takeo, Anil Kashyar, and David Scharfstein, 1991, "Corporate Structure, Liquidity, and Investment: Evidence from Japanese Industrial Groups," Quarterly Journal of Economics, Vol. 106, pp. 33-60.

Hubbard, Glenn, Anil Kashyar, and Toni Whited, "Internal Finance and Firm Investment," Journal of Money, Credit, and Banking, Vol. 27, pp 683-701.

Jarrow, Robert, and Stuart Turnbull, 1995, "Pricing Derivatives on Financial Securities Subject To Credit Risk," Journal of Finance, Vol. 50, pp. 611-625.

Jarrow, Robert, David Lando, and Stuart Turnbull, 1997, "A Markov Model For The Term Structure of Credit Risk Spreads," Review of Financial Studies, Vol. 10, pp. 481-523.

Jones, E. Phillip, Scott. Mason, and Eric Rosenfeld, 1984, "Contingent Claims Analysis of Corporate Capital Structure: An Empirical Investigation," Journal of Finance, Vol. 39, pp. 611-625.

Kashyap, Anil, Owen Lamont, and Jeremy Stein, 1994, "Credit Conditions and the Cyclical Behavior of Inventories," Quarterly Journal of Economics, Vol. 109, pp. 565-592.

Kim, In Joon, Krishna Ramaswamy, and Suresh Sundaresan, 1992, "The Valuation of Corporate Fixed Income Securities," Working Paper (New York: New York University). 
Kiyotaki, Nobuhiro and John Moore, "Credit Cycles," Journal of Political Economy, Vol. 105, pp. 211-248.

Litterman, Robert, and Thomas Iben, 1991, "Corporate Bond Valuation and The Term Structure of Spreads," Journal of Portfolio Management, Vol. 17, pp. 52-64.

Mella-Barral, Pierre and William Perraudin, 1997, "Strategic Debt Service," Journal of Finance, Vol. 52, pp. 531-56.

Merton, Robert C., 1974, "On The Pricing of Corporate Debt: The Risk Structure of Interest Rates," Journal of Finance, Vol. 29, pp. 449-470.

Myers, Stewart C., 1984, "The Capital Structure Puzzle," Journal of Finance, Vol. 39, pp. $575-592$.

Moody's Investors Service, 2002a, Default \& Recovery rates of Corporate Bond Issuers. A Statistical Review of Moody's Rating Performance 1970-2001, February.

Moody's Investors Service, 2002b, Moody's Credit Perspectives, Vol. 95, No. 3.

Schwert, William, 1989, "Why Does Stock Market Volatility Change Over Time?" Journal of Finance, Vol. 44, pp. 1115-11153.

Sharpe, Steven, 1994, "Financial Market Imperfections, Firm Leverage, and the Cyclicality of Employment," American Economic Review, Vol. 84, pp. 1060-1074.

Stock, James, and Mark Watson, 1993, "A Procedure for Predicting Recessions With Leading Indicators: Econometric Issues And Recent Performance," in Business Cycles, Indicators, and Forecasting, ed. By James Stock and Mark Watson (Chicago: University of Chicago Press).

,2001, "Forecasting Output and Inflation: The Role of Asset Prices," NBER Working Paper No. 8180 (Cambridge, Massachusetts: National Bureau of Economic Research).

Weiss, Lawrence, 1990, "Bankruptcy Resolution: Direct Costs and Violation of Priority of Claims," Journal of Financial Economics, Vol. 27, pp. 285-314.

Wruck, Karen, 1990, "Financial Distress, Reorganization, and Organizational Efficiency," Journal of Financial Economics, Vol. 27, pp. 419-446. 